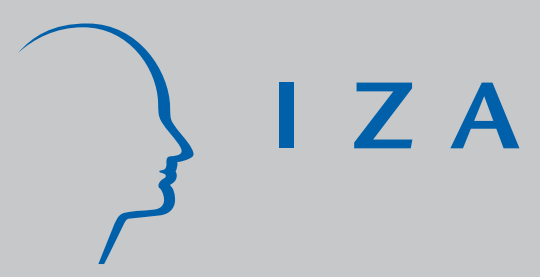

IZA DP No. 4086

Estimating the Social Value of Higher Education: Willingness to Pay for Community and Technical Colleges

Glenn C. Blomquist

Paul A. Coomes

Christopher J epsen

Brandon C. Koford

Kenneth R. Troske

February 2009 


\title{
Estimating the Social Value of Higher Education: Willingness to Pay for Community and Technical Colleges
}

\author{
Glenn C. Blomquist \\ University of Kentucky \\ Paul A. Coomes \\ University of Louisville \\ Christopher Jepsen \\ University of Kentucky \\ Brandon C. Koford \\ Valdosta State University \\ Kenneth R. Troske \\ University of Kentucky and IZA
}
Discussion Paper No. 4086
February 2009

\author{
IZA \\ P.O. Box 7240 \\ 53072 Bonn \\ Germany \\ Phone: +49-228-3894-0 \\ Fax: +49-228-3894-180 \\ E-mail: iza@iza.org
}

\begin{abstract}
Any opinions expressed here are those of the author(s) and not those of IZA. Research published in this series may include views on policy, but the institute itself takes no institutional policy positions.

The Institute for the Study of Labor (IZA) in Bonn is a local and virtual international research center and a place of communication between science, politics and business. IZA is an independent nonprofit organization supported by Deutsche Post Foundation. The center is associated with the University of Bonn and offers a stimulating research environment through its international network, workshops and conferences, data service, project support, research visits and doctoral program. IZA engages in (i) original and internationally competitive research in all fields of labor economics, (ii) development of policy concepts, and (iii) dissemination of research results and concepts to the interested public.
\end{abstract}

IZA Discussion Papers often represent preliminary work and are circulated to encourage discussion. Citation of such a paper should account for its provisional character. A revised version may be available directly from the author. 


\section{ABSTRACT \\ Estimating the Social Value of Higher Education: Willingness to Pay for Community and Technical Colleges ${ }^{*}$}

Much is known about private returns to education in the form of higher earnings. Less is known about social value, over and above the private, market value. Associations between education and socially-desirable outcomes are strong, but disentangling the effect of education from other causal factors is challenging. The purpose of this paper is to estimate the social value of one form of higher education. We elicit willingness to pay for the Kentucky Community and Technical College System directly through a stated-preferences survey and compare our estimate of total social value to our estimates of private value in the form of increased earnings. Our earnings estimates are based on two distinct data sets, one administrative and one from the U.S. Census. The difference between the total social value and the increase in earnings is our measure of the education externality. Our work differs from previous research by eliciting values directly in a way that yields a total value including any external benefits and by focusing on education at the community college level. Our preferred estimate indicates the social value of expanding the system substantially exceeds private value by approximately 50 percent.

JEL Classification: $\quad$ 12, $\mathrm{H} 4, \mathrm{H} 23$

Keywords: social returns, education externalities, contingent valuation, earnings

Corresponding author:

Kenneth R. Troske

Department of Economics

Gatton College of Business \& Economics

Building 335

University of Kentucky

Lexington, KY 40506-0034

USA

E-mail: ktroske@uky.edu

\footnotetext{
*For comments we thank Magnus Johannesson, Juanna Joensen and workshop participants at the Baltic International Center for International Policy Studies, Stockholm School of Economics, University College Dublin, University of Kentucky, the University of Louisville, and the 2009 North American Meetings of the Regional Science Association. Barry Kornstein at the University of Louisville provided assistance in estimating the returns using Census data. Christina Whitfield and Alicia Crouch helped greatly in getting the KCTCS data. Glenn Blomquist acknowledges support of colleagues at the Stockholm School of Economics while on sabbatical. This research was funded in part by the Kentucky Community and Technical College System. The authors alone are responsible for findings and views contained in this paper.
} 


\section{Introduction}

A great deal is known about the private returns to education for the individual in the form of higher earnings. Less is known about the social value of education over and above the private, individual, market value, but the interest in the difference is great. The association between education and socially desirable outcomes is strong and widely acknowledged, but disentangling the effect of education from other potential causal factors has been challenging and relied primarily on instrumental variable strategies.

We take another approach. The purpose of this paper is to estimate the social value of one form of higher education. We elicit willingness to pay for the Kentucky Community and Technical College System directly through a stated preference, contingent valuation survey and compare our estimate of total social value to estimates of private, individual value in the form of increased earnings. Community colleges are important because they are the "Ellis Island of American higher education” providing a route to higher incomes for many lower income individuals (College Board, 2008).

Our estimates of increased individual earnings are based on two distinct data sets for Kentucky, one administrative and one from the U.S. Census. The difference between the total social value and the increase in individual earnings is our measure of the education externality, or human capital spillover. We compare our estimates of social value to estimates based on the effects of area average education in the individual earnings equations. In our preferred estimates, the social value of expanding the system substantially exceeds private value (i.e. higher earnings) by approximately 50 percent.

Our work differs from previous research by focusing on higher education at the community college level and by using unique administrative data on community college students. In addition, it differs by eliciting values directly through contingent valuation 
in a way that yields a total value that includes increased earnings and any spillover benefits in the form of increased productivity or enhanced quality of life for others in the area.

2. Individual, Private Value of Education

Workers with higher education typically have higher earnings. Card (1999) summarizes a vast literature on individual returns to education with discussions of various estimation techniques. Straightforward, single equation estimates show that an additional year of schooling raises yearly earnings five to ten percent. More complex estimation strategies attempt to determine the causal effect of education on earnings by separating the effects of ability and other factors that can be correlated with schooling from the effect of schooling. These analyses use multiple equations and/or special populations such as identical twins tend to find higher returns - at or above ten percent. Heckman, Lochner, and Todd (2006) scrutinize this research based on the Mincer (1974) equation and estimate more general, nonparametric earnings models that allow for earnings to vary by year after completion (nonlinearity) and allow for the nonstationarity of earnings over time. Their analysis shows (1) assuming linearity leads to a downward bias to the return, (2) taking into account taxes has little impact on the return estimates, (3) taking into account tuition costs of schooling lowers the return to college by a few percentage points, and (4) psychic costs can be a barrier. Their work emphasizes that the private returns to education are substantial. 
The private value of education is not limited to higher labor market earnings for the individual. ${ }^{1}$ The reason, as described by Grossman (2006), is that the knowledge an individual acquires through education accompanies that person to the workplace where more is earned and also to the clinic where health is produced, to the kitchen where meals are produced, and to the ski slope where exercise is produced. Education leads individuals to be more efficient in producing the commodities they consume directly. Higher education leads to more output from the same inputs (production efficiency), similar to an increase in technology, and/or a more efficient mix of inputs to production (allocative efficiency.) The implication is that the return to schooling is underestimated if the benefits are restricted to market earnings; the nonmarket return may be at least half the size of the market return as Grossman (2006) notes.

Better health is thought to make up a large share of the nonmarket return. Cutler and Llera-Muney (2008) analyze the large and persistent association between education and health and show that the widely-acknowledged associations between education and both income and occupation account for only part of the association between education and health. Their rough estimate of the value of increased life expectancy due to education raises the private, individual returns to education by 15 to 55 percent. The estimate would be even greater if it included improvements in quality of life.

Becker and Murphy (2007) consider various differences between the impacts of education in the household and the market. Returns in the household are over many tasks such as managing finances, making meals, keeping a dwelling livable, providing health care, and raising children. Returns in the market, in contrast, are typically to a few

\footnotetext{
${ }^{1}$ For a catalog of schooling outcomes that would be included in nonmarket private returns and social returns see Wolfe and Haveman (2002). Intrafamily productivity, marital choice efficiency, health of children, crime reduction, charitable giving, and social cohesion are on their list.
} 
specialized tasks. They argue that due to accumulation of general skills that are especially useful in the modern household, the returns to education in the household sector may have grown more than in the market over the last 40 years. As we discuss below, the contingent valuation method we use to measure the returns to education should be able to capture these non-market private returns to schooling. However, we will not be able to separate the non-market private returns from the social returns to schooling.

All returns discussed so far accrue to individuals who are, to be sure, part of society. Our interest, however, is in estimating the extent to which the value of education exceeds the value to the individual, i.e., the extent to which social value exceeds the private value.

\section{Social Value of Education}

The idea that education generates benefits beyond the private gains to individuals is fundamental. Two specific, related lines of thinking have endured. One is related to overall quality of life in an area. The other is related to productivity in the labor market. Quality of life can be enhanced because society functions better with individuals who have better cognitive skills. Higher education can lead people to live in ways that contribute more to public health, behave in ways that promote less crime, and act in ways that contribute more to civic activity and good governance. Within labor markets, higher education can lead to greater productivity through agglomeration economies and higher rates of economic growth. Workers can learn from one another. 
a. Health. Grossman (2006) reviews evidence that parents with more education produce children with better health. However, that valuable effect is within and internal to the household. Evidence of spillover health benefits outside the household comes from Wheeler (2008) who analyzes a panel of more than 200 U.S. metropolitan areas between 1990 and 2000. He uses city age distribution in 1980 and presence of a land grant college, two instruments developed by Moretti (2004a), to account for endogeneity in area-level education rates. He finds that higher education in the area is associated with lower mortality rates that are conditional on age, race, gender, and education. A 5 percentage point decrease in the share of college graduates corresponds to a 14-40 percent increase in the probability of death. The mortality rates for deaths caused by heart disease and cancer are lower for areas with more aggregate human capital. These causes are known to be associated with lifestyle that Kenkel (1991), for example, has shown to be related to health knowledge and schooling. One explanation for the education externality is that others learn from the behavior of individuals with more education and benefit from it. Their behavior contains information and following it can be beneficial just as buying the market leader in a product market can be a good practice. Although the spillover health benefit estimated by Wheeler is already large, presumably mortality rates from communicable diseases would be affected to an even greater extent than deaths from heart attack and cancer. Fortunately their prevalence is low in the U.S. cities during the period studied and data are insufficient to measure the effect.

b. Crime. Quality of life is better in areas where crime is lower. Lochner and Moretti (2004) use U.S. Census and Federal Bureau of Investigation data from the 1960s, 1970s, and 1980s and estimate that an extra year of schooling results in a 0.10 point 
reduction in the probability of incarceration for whites and a 0.37 point reduction for blacks. The greatest impact on arrests is for murder, assault, and motor vehicle theft. They follow Acemoglu and Angrist (2000) and use compulsory school attendance laws as an instrument for area-level education rates. Lochner and Moretti (2004) estimate that the external effect of education through reducing crime is 14 to 26 percent of the private return to schooling.

c. Good Government. Better public governance contributes to quality of life in the area. Education is considered an essential ingredient of a successful democratic society because education encourages individuals to participate and equips them to do so effectively; see for example Friedman (1962). Dee (2004) analyzes the relationship between education and voting using data from High School and Beyond survey for 1980 to 1992 and the General Social survey from 1972 to 2000. He relies upon geographic proximity to community colleges as a teen as an instrument for area-level education in the High School and Beyond data. College entrance increases voter participation by 17 to 22 percentage points. Relying on teen exposure to child labor laws as an instrument for area-level education in the General Social Survey, Dee (2004) finds that an additional year of schooling increases civic engagement through voting, newspaper readership, and support for free speech.

Milligan, Moretti and Oreopoulos (2004) also find a strong relationship between schooling and voting using 1948-2000 National Election Studies data for the U.S. They use state in which the respondent received the education as an instrument. The effect of high school graduation is to increase the probability of voting by approximately 30 percentage points. This effect works primarily through an increase in voter registration. 
Little effect is found for the United Kingdom, a result they attribute to the high voter registration rate (94 percent) in the UK. More educated citizens have more information related to candidates and campaigns in both countries. Presumably education continues to influence civic participation beyond high school.

Increased voter participation by a better informed public can be expected to improve the quality of governance as measured by less corruption. Glaeser and Saks (2006) study federal convictions for corruption using 1976 to 2002 U.S. Department of Justice data collected from Reports to Congress on Activities and Operations of the Public Integrity Section. They assemble data to generate conviction rates for each state. Because Congregationalists are known for their commitment to education, Congregationalist church membership as a fraction of state population in 1890 and median household income in 1940 are used as instruments for area-level education rates. States with more education are found to have lower rates of federal corruption convictions. A one standard deviation increase in the fraction with at least four years of college education is estimated to reduce convictions by at least half of a standard deviation using ordinary least squares (OLS) and almost twice that reduction using the instrumental variable (IV) estimate.

d. Productivity and Growth. To this point we have reviewed evidence that people living in areas populated by individuals with higher education can benefit through an education externality that enhances their quality of life through better health, less crime, and better governance with greater voter participation and less corruption of public officials. A second related line of thinking is that people working in areas populated by workers with higher education can benefit through higher productivity and growth. The 
idea that workers are made more productive by those around them is one form of agglomeration economies that explains why cities exist, and it is a major factor in modern growth theory.

Moretti's (2004b) review of research on human capital externalities in cities describes the readily observable association between higher education and higher productivity. In addition, he describes the difficulty in attributing the higher productivity and wages to education alone. The challenge of endogenous education attainment in an area arises because workers are also consumers. Individual consumer/workers choose location after considering wages, cost of living, and the bundle of amenities available in the area. Moretti (2004a) estimates productivity spillovers by estimating a Mincer (1974) wage equation with an additional variable that measures the share of college graduates in the labor force in the area. He uses data from the 1970, 1980, and 1990 U.S. Census with presence of a land grant college and lagged city demographic structure as instrumental variables for area-level education. A one percentage point increase in college share in a city is estimated to increase average wages (the externality) by 0.4 to 1.9 percent. $^{2}$ Moretti (2004b) notes, however, that there is little consensus among studies in the size of the education externality. He concludes his review by saying the empirical literature is too young to draw definitive conclusions about the size of the education externality. Lange and Topel (2006) critically review the existing studies on social returns to education and the evidence that the "Macro-Mincerian" (social) return is greater than the "Micro-Mincerian” (private) return. Their assessment of cross-country studies using

\footnotetext{
${ }^{2}$ How close must educated workers be to make other workers more productive and receive higher wages? Rosenthal and Strange (2008) use 2000 U.S. Census data on workers and cities and concentric ring variables at various distances from a worker's place of employment to estimate the attenuation of human capital spillovers. City fixed effects and additional differencing is done to account for possible endogeneity of area human capital. Rosenthal and Strange find productivity externalities that are concentrated in the 0 to 5 mile ring. The spillover is several times smaller in the 5 to 25 mile ring.
} 
aggregate data is that evidence of education externalities is inconclusive. Their own spatial equilibrium model of local wage determination suggests that insufficient weight has been given to endogeneity issues in analyses of wages in cities and states in the United States. Correlations of proposed instrumental variables with the value of local amenities for the marginal worker are of particular concern. The nature of compulsory schooling laws that raise completion rates for high school and not higher education is another concern. Lange and Topel (2006) provide new evidence by analyzing human capital and wage and productivity growth using individual data from the 1940-2000 U.S. Census. As in earlier studies, they find a positive impact of average schooling on local wages after controlling for private returns. However, unlike earlier studies, the impact shrinks when a measure of labor force quality is included. ${ }^{3}$ Lange and Topel (2006) draw the conclusion that the results do not provide a strong reason to believe in the importance of productivity externalities from education. ${ }^{4}$

Compared to the enormous volume of research on the private returns to education, the volume on spillovers or externalities associated with education is small. The association between education and area quality of life and area productivity is clearly positive and strong. The estimates of the size of the externality caused by education, however, are sensitive to the instrumental variables used. We use an alternative approach that elicits the social value of education directly.

\section{Eliciting Willingness to Pay for Higher Education}

\footnotetext{
${ }^{3}$ Yamarik (2008) uses a panel of state level data to estimate a macro-Mincer model and also finds social returns that are approximately the same as private returns.

${ }^{4}$ Lange and Topel (2006) also discuss the signaling model of education that implies the spillover effect is negative. They conclude signaling is a minor contributor to the returns to schooling.
} 
To obtain estimates of the value individuals place on goods and services, we typically look to markets. However, social outcomes related to education such as better quality of life and higher productivity and growth in an area, are goods not traded in the market explicitly. Contingent valuation is a survey-based methodology used for placing monetary values on goods with public benefits or goods which are difficult to value in the marketplace (Carson 2000). The method is often called a stated-preference method because it asks respondents to state what they would be willing to pay to obtain the good or service described in the survey. The estimate of total value includes the individual benefits the respondent receives, in addition to the value the respondent places on any public benefit to others. The contingent valuation method provides a way to value goods for which there is not a well-functioning market. Contingent valuation creates a scenario in which individuals are asked to state their willingness to pay (WTP) for the good or service described. In essence, the contingent valuation method sets up a market where none existed.

Early studies of the social value of education have used surveys to obtain information regarding household level voting behavior on referendums that determined the level of funding for local public education. Rubinfeld (1977) uses a survey to determine household level preferences regarding a local school election in a Detroit suburb. Exploiting variation in the tax obligation of households, he estimates income and price elasticities of demand for public education. In the Marshall, Michigan school district, voters were asked to consider a change in the property tax millage rate that funded public schooling. Lankford (1985) employs an ex-post survey of Marshall school district residents to inquire about their voting behavior. The data are used to obtain 
mappings of citizens’ preferences and infer demand estimates for public education. Bergstrom et al. (1982) employ a survey to ask individuals’ opinions about the level of state and local government funding for public education. Respondents are asked if they would rather the government spend more, less, or about the same on the local public school systems as compared to current levels. They find that the implied estimates of income elasticity ( 0.4 to 0.8 ) for public education using micro-data are similar to studies using aggregate data and employing median-voter models.

Two studies use contingent valuation to value different forms of education. Escobar et al. (1988) estimate the value of preschool education for handicapped children. Parents of handicapped children in the area of Sioux City, Iowa are asked how much they would be willing to pay for their children's public preschool education if it were not free. Parents are presented with a range of values from $\$ 0$ to $\$ 10,000$ and are asked to indicate their willingness to pay by marking one of the dollar amounts. The average willingness to pay is $\$ 573$ per family, although willingness to pay varies greatly with respect to the particular form of handicap. A problem with the Escobar et al. study is that they do not survey a representative sample of the population, something that is necessary in order to capture the social value of a good. Stair et al. (2006) use a representative sample of residents in two rural Pennsylvanian school districts to estimate the value of increased quality at area high schools. Residents are found to be willing to pay a sum that equates to roughly 23 percent of the local education budgets for an increase in the quality of the school, where quality is measured by a 10 percentage point increase in statewide test scores. Theses results, however, are the product of elicitation using an unconventional 
format with unknown reliability. None of the existing studies focuses on the social value of higher education. ${ }^{5}$

In this study, we estimate the total value of the Kentucky Community and Technical College System (KCTCS) using contingent valuation. Although certain market transactions take place for individuals wanting to attend KCTCS, those transactions alone do not represent the total value of KCTCS. The reason is some of the benefits of education can accrue to society as a whole and not just to individuals taking classes. Capturing the total social value of the system requires an estimation of the combined benefits that accrue to the individual and, if an education externality exists, society as a whole. This total value is estimated by sampling the population of Kentucky and offering individuals the opportunity to state their total value for KCTCS. This total value includes any benefit the survey respondent may receive personally if the individual attends KCTCS, and it also includes any other benefits the individual may receive such as better public decision making or higher area level productivity.

5. Eliciting Willingness to Pay for the Kentucky Community and Technical College System

We elicit willingness to pay by administering a survey to a sample of Kentucky residents. The first section of our survey instrument includes questions designed to assist respondents in thinking about their experience with and knowledge of KCTCS. In the second section, respondents are asked to allocate a fixed increment in state budget dollars to various state program areas. This section reminds respondents that increased spending in one budget area has opportunity costs. We also asked questions designed to stimulate

\footnotetext{
${ }^{5}$ Contingent valuation has been applied to a few social policies; see Drago et al. (2001) and Cawley (2006).
} 
respondent thinking about the different types of benefits they might receive from KCTCS. The third section contains the valuation scenario along with questions regarding response certainty. Although all parts of the survey must work together to elicit an accurate valuation from respondents, the valuation section is the most critical. In this section respondents were asked to state their value of KCTCS. To obtain valuations, the survey asked individuals if they would be willing pay a specified dollar amount for a 10 percent expansion in KCTCS. We focus on a 10 percent expansion because it is plausible to think about expanding the system by 10 percent and because it is the change for which we have the best data. In the last section, demographic information was collected in order to allow us to analyze willingness to pay by respondent characteristics such as gender, age, income, and education levels.

The survey described the expansion in terms of the number of programs offered through the community and technical college system. The proposed 10 percent expansion would increase the number of programs offered from 96 to 105 and be accompanied by an accommodating increase in the number of faculty, staff, and structures. The survey was used to create a hypothetical referendum in which respondents had a chance to vote for or against the proposed expansion. While various valuation formats exist, our study follows Arrow et al. (1993) and uses the dichotomous choice referendum format. The respondent was told that if the referendum passed, there would be a one-time increase in taxes. The respondent was asked the following question: "Would you vote for the referendum to expand the Kentucky Community and Technical College System by $10 \%$ here and now if you were required to pay a one time $\$ T$ out of your own household budget?” 
where $T$ was an amount from the following set: 400, 250, 200, 150, 125, 100, 75, and 25.

Only one tax amount was presented to each respondent, but different amounts were

presented to different individuals so that the value of KCTCS could be estimated. The

values of the tax were chosen based on input from focus groups and from data received

from testing the survey. ${ }^{6}$

Knowledge Networks, a privately-owned firm specializing in survey research, administered the survey in June and July 2007. The survey data was collected using two samples. The first sample consisted of respondents in Kentucky drawn from Knowledge Networks’ nationally representative web panel. For this sample, the survey was administered online. The second sample was based on a white pages phone number random sample of Kentucky. Addresses were matched to phone numbers and the mail sample was distributed proportionally across the state. The response rate from the web panel was 74 percent (275/370), and the response rate from the mail survey was 29 percent $(2,681 / 9,196)$. The response rate for the survey overall was 31 percent $(2,956 / 9,566)$. The number of usable observations for this study is $1,023 .^{7}$ Despite the good professional practices of Knowledge Networks, the lower response rate of the mail version is not unusual for a complex survey like this one. However, it leads to the

\footnotetext{
${ }^{6}$ Two professionally moderated focus groups consisting of Kentuckians were conducted to ensure that respondents' understanding and interpretation of the survey questions matched the intention of the survey authors. One group consisted of eight members of the Donovan Scholar Program, who are individuals over age 65 who are attending selected classes at the University of Kentucky. The second focus group consisted of eight returning students who are attending the Maysville Community and Technical College. Focus groups were recorded and the results were used to refine elements of the survey. The complete survey instrument is available on line at http://gatton.uky.edu/CBER/pdf/CBER_UL_KCTCSReport_10-2007.pdf. ${ }^{7}$ Knowledge Networks invited 370 members of its web panel to participate in the web-based sample. 275 responded yielding a response rate of 74 percent. The mail-based sample consisted of an initial mailing of 10,000 households. 804 were undeliverable. A total of 2,681 surveys were returned for a response rate of 29 percent $(2,681 / 9,196)$. Not all 2,956 web and mail observations are usable due to: a wording error on two versions of the survey $(1,486)$, protestors who did not vote for the referendum and indicated in a follow up question "my household should not have to pay more taxes to fund the expansion" (261), and item nonresponse for variables in the logit regression (186). The number of remaining usable observations from the web (109) and mail (914) surveys is 1,023.
} 
question of whether the mail-based sample suffers from non-response bias. Fortunately, the demographic characteristics of the high-response rate, web-based sample, the lower response rate mail-based sample, and the values from Census data are all similar.

Table 1 compares demographic information for the two sets of survey respondents and for the U.S. Census Bureau's 2007 American Community Survey (ACS). Compared to the ACS, the KCTCS survey sample is quite similar. The similarity of these observable characteristics suggests that non-response bias may not be an issue. ${ }^{8}$

Another potential issue is bias due to the hypothetical nature of a constructed market. Since the inception of the contingent valuation method, there have been concerns over its use. Chief among those concerns is the possibility that respondents will not take the hypothetical nature of the survey seriously. Because no money changes hands, there is doubt that the hypothetical responses reflect what people would do if they actually had to pay money based on their decisions. Response to this concern has produced research in which hypothetical purchase decisions and real purchase decisions are compared. The hypothetical and real scenarios vary only in the fact that some respondents are asked if they would pay, while others are asked if they will pay. Hypothetical bias occurs when contingent valuation respondents state they are willing to pay more for a good than they would be willing to pay in an actual purchase scenario. Frequently results indicate significant "hypothetical bias" exists (Blumenschein et al. 1997; List and Gallet 2001; Little and Berrens 2004; Harrison 2006).

\footnotetext{
${ }^{8}$ Another indication, and one that might tell something about unobservable characteristics, is that when we control for whether an observation comes from the high response web survey or the lower response mail survey, the coefficient on the dummy variable for the web survey is not statistically different from zero. This result will be reported in Table 3 below for the logit analysis of the contingent valuation referendum responses.
} 
Several approaches have shown promise in eliminating hypothetical bias in estimating willingness to pay using contingent valuation (Champ and Bishop, 2001, Cummings and Taylor, 1999, and Poe et al., 2002). In this study, we use follow up questions about how certain the respondents are that they will really pay to calibrate responses. After respondents answer the willingness to pay question, they are asked to indicate whether they are "probably sure” or "definitely sure” about their decision. Only respondents who say "yes" and are "definitely sure” are counted as giving true or real "yes" responses. All respondents who say "no" and respondents who say "yes" but are only "probably sure" are counted as "no" responses. Experiments in the classroom and field by Blumenschein et al. $(1998,2008)$ using this follow up certainty question mitigation method have produced calibrated hypothetical responses that are similar to comparable real responses.

For example, Blumenschein et al. (2008, Fig. 2, p. 127) show a plot of price against percentage buyers for a field experiment in which a health management program was offered to individuals for real. Similar "demand curves" are shown for contingent valuation of the same good for both all "yes" responses and for calibrated "yes" responses. The calibration is that only "definitely sure yes" responses are classified as true "yes” responses. The demand curve for all “yes” responses is noticeably (and statistically) higher than the real demand curve. The hypothetical demand curve based on certainty-calibrated “yes” responses is virtually (and statistically) indistinguishable from the real demand curve. In other words, the hypothetical bias is not statistically significant after the calibration. We report our estimates of willingness to pay based on responses 
calibrated for certainty in this way. For comparison we also report estimates based on counting all "yes" responses as true "yes” responses.

6. Results and Estimates of Total, Social Value

Each respondent is presented only one tax price, $T$, for the expansion of KCTCS, and the respondent makes a decision about willingness to pay that amount. In this referendum style contingent valuation respondents do not reveal the exact value of their willingness to pay. Instead, respondents answer "yes" if their willingness to pay is greater than $T$ and "no" otherwise. Because a total of eight different tax prices were used for different respondents, the sample average willingness to pay can be estimated. To analyze responses, we use a logistic regression. The dependent variable is the certaintyadjusted vote response and the independent variables include the amount of the tax, $T$, faced by the respondent and controls for age, sex, race, income, education, and experience with KCTCS. When willingness to pay for a particular policy is believed to be non-negative, the estimates from the logistic regression are combined using the formula: - $\left(1 / b_{T}\right) \ln \left(1+e^{z}\right)$ where $b_{T}$ is the coefficient on the variable associated with the amount of the tax and $z$ represents the effect of all of the other covariates evaluated at their means, including the constant (Johansson 1995). While some households may place a low or zero value on higher education, there was no indication of negative values in the focus groups. ${ }^{9}$ The result is an estimate of the total, social value (private value plus any spillovers) of an average household in the Commonwealth of Kentucky for a 10 percent increase in the size of KCTCS.

\footnotetext{
${ }^{9}$ Epstein (2003) evaluates the case for using contingent valuation and notes that, in general, possible negative values should not be ignored.
} 
Table 2 gives the definitions and summary statistics for each variable used in the logit regression of contingent valuation responses. In addition to demographic characteristics there are three variables related to information about KCTCS. Twenty seven percent have taken a class from KCTCS, 53 percent have a family member who has taken a class, and 27 percent know an employee of KCTCS. Clearly respondents are familiar with KCTCS. Two additional variables are used to control for version of the survey. Based on a split sample study design some respondents were presented with a referendum and tax amount to prevent either a 10 or 25 percent reduction in the KCTCS and were also given a "cheap talk" exhortation to avoid hypothetical bias; see Cummings and Taylor (1999). Because we focus on the 10 percent expansion and use the follow up certainty questions to mitigate hypothetical bias and we want to control for any combined reduction, cheap talk effect, we include the two variables for reduction/exhortation. ${ }^{10}$

Logit regressions of the referendum responses are shown in Table 3. Only definitely sure "yes" responses are coded as true "yes" responses; other responses are coded as "no" responses. The calibration matters because of the 564 "yes" responses, only 272 are definitely sure they would really be willing to pay the increase in taxes.

The coefficient of the tax amount is negative and statistically significant. The marginal effect of an increase of $\$ 50$ is estimated to reduce the probability of voting "yes” by four percentage points. Income matters especially at higher levels. The “marginal effect” of moving from the under $\$ 25,000$ base category to the $\$ 60-99,000$ category is plus 13 percentage points and moving from that category to the top income category adds approximately another 13 percentage points. Education tends to increase

\footnotetext{
${ }^{10}$ Because of a wording error on the survey we do not have parts of our sample that permit perfectly clean tests for the effects of cheap talk or reductions separately. We simply control for their combined effects. See footnote 14 for a discussion of the implications for sample size.
} 
the probability of support, but the effects are imprecisely estimated. Support for KCTCS tends to increase with age and is strongest in the two oldest age groups. The probability of support is 21 percentage points higher for respondents age 65 and over compared to younger individuals in the 18 to 29 category. One interpretation of the stronger support among older respondents is that it is an indication of an education externality; individuals 65 and older are less likely to earn certificates, diplomas, or degrees and reap the benefits of higher earnings. Support is greater for respondents whose family members have attended KCTCS and for those who know someone who works for KCTCS. The coefficient indicating that individuals were part of the web survey is not statistically different from zero at conventional levels. ${ }^{11}$

In addition to asking about willingness to pay for expansion of the KCTCS, we asked respondents about perceived benefits they receive from education. We asked respondents to allocate points to the various benefit categories. Respondents were told that allocating more points to a given category indicated that they believed education provided more benefit in the given category. Allocating no points to a given category indicated that they believed education produced no benefits to the given category. The results appear in Table 4. Respondents clearly believe that one of the main benefits from education is the additional economic development that occurs as the result of the increased education of the workforce. ${ }^{12}$ Respondents also believe that an increase in the

\footnotetext{
${ }^{11}$ The results reported above are based on the pooled sample that includes responses from the web and mail surveys. We stratified and estimated logits of the yes/no responses for the web and mail subsamples. Differences across the two are not significant at the 5 percent level.

${ }^{12}$ Despite a separate category for "local purchases," respondents may be considering the local impact of a nearby community college rather than the local spillover benefits from enhanced human capital. They may be thinking about the cash inflow from state-provided payrolls and expenditures and the impact on local sales. See Siegfried, Sanderson, and McHenry (2007) for an exemplary discussion that makes a clear distinction between distributional impacts and efficiency spillovers associated with colleges and universities.
} 
wages of students, an increase in the speed of technological change and a fall in crime are all additional important benefits from education that occur in approximately equal amounts. According to respondents, two other important benefits are improved health of students who receive additional schooling as well as improved public decision making. The fact that respondents believe that higher wages are one of the primary benefits from additional schooling is consistent with the well-established result that private, individual returns to school are substantial. The fact that respondents believe that reduced crime, improved health and better public decision making are all important benefits of schooling is consistent with our finding that public benefits are an important component of the total benefits from higher education.

Another way to view these results is to group the categories. Individual, private benefits in the form of "wages of attendees" and "own health" are at least about 24 percent of the total. Spillover productivity benefits in the form of "economic development," "technology," and "wages of non-attendees" are about 39 percent. If “crime” and "better public decision making” and "health of non-attendees” are added to spillover productivity benefits, they are about 68 percent of the total. Although the results from this point allocation exercise may be interesting, they were included primarily to encourage respondents to think about why they value education. They are not estimates of social value. Willingness to pay is estimated from the responses to the contingent valuation referendum. ${ }^{13}$

\footnotetext{
${ }^{13}$ In Appendix Table A1 we report logit results that include two variables that combine the points allocated to quality of life (Crime, Better Public Decision Making, and Health of Non-Attendees) and productivity growth (Economic Development, Technology, and Wages of Non-Attendees). We also explored variables for the effect of a KCTCS campus being located in the county of residence, population density of the county of residence, and years the respondent has lived in Kentucky. None of these variables were statistically significant at conventional levels. The coefficient on Tax Amount, the key variable for estimating mean WTP, is influenced little by their inclusion. A set of dummy variables for regions in
} 
Willingness to pay for the 10 percent expansion of the KCTCS is estimated using the Johansson (1995) formula (on page 19 above) evaluated at the means of the variables. The parametric demand curve is estimated based on calibration with definitely sure "yes" coded as “yes” and equal to one and all three other responses coded as "no" and equal to zero. The parametric demand curve using this calibration to eliminate hypothetical bias is shown as the solid line in Figure 1. The mean WTP based on this calibration is $\$ 55.84$. The 90 percent confidence interval estimated using the delta method is [41.75, 69.92]. This WTP per household is our best estimate of the total social value of a 10 percent expansion of the KCTCS. ${ }^{14}$ It includes the private individual returns through earnings and health as well as any spillovers to others through higher wages, better health, household productivity, less crime, and better government. According to the ACS, there were 1.65 million households in Kentucky in 2005. Our estimate of aggregate willingness to pay for Kentucky households is $\$ 92.1$ million with a 90 percent confidence interval of [68.9, 115.4]. This estimate includes the private returns and any education externality which is realized through higher productivity and overall quality of life for others.

Kentucky was included in preliminary regressions, but they were jointly statistically insignificant and were dropped with little effect on remaining variables.

${ }^{14}$ If we restrict the sample to only respondents who were asked about a 10 percent expansion, we can eliminate the two control variables for cheap talk and reductions combined. This greatly reduces the sample size from 1023 to 526 and slightly reduces the estimate of mean WTP from \$55.84 to \$51.67. If we use the means from ACS 2007 where available instead of the means from our sample in evaluating the logit, the estimate of mean WTP is increased slightly from $\$ 55.84$ to $\$ 57.92$ [43.05, 72.79]. The nonparametric point estimates of mean WTP are substantially higher. The Turnbull estimate is $\$ 72.66$ with a 90 percent confidence interval of [62.02, 83.31] which overlaps the confidence interval for the parametric estimate [41.75, 69.92]. The Kriström estimate of \$94.95 [86.28, 103.61] does not overlap. Although we believe our sample is representative overall, we have less confidence that it is representative for the cells for each of the eight tax amounts. The parametric estimates control for differences in income, age, education and other observable characteristics and are our preferred estimates. 
Our calibration using definitely sure "yes” is based on correcting for hypothetical bias in valuing private goods. For example, in the field experiment described in Blumenschein et al. (2008) the good was a diabetes management program provided by a pharmacist to an individual patient. KCTCS expansion presumably is a partly-private and partly-public good. Calibration may be different for private and public goods because strategic behavior can bias estimates of WTP. Free riding could produce underestimates while hypothetical bias could produce overestimates. Carson and Groves (2007) make the case that a single issue, dichotomous choice, referendum format that respondents believe will have influence public decisions will be incentive compatible. The meta-analysis by Little and Berrens (2004) provides evidence that referendum format for contingent valuation reduces hypothetical bias for public goods. For comparison, in Figure 1 the dashed line shows the parametric demand curve for all (unadjusted) “yes” responses. The mean WTP for all who say “yes” is $\$ 212.21$. The 90 percent confidence interval estimated using the delta method is [175.53, 248.89]. The estimate of aggregate willingness to pay for Kentucky households is $\$ 350.1$ million with a 90 percent confidence interval of [289.6, 410.7]. Clearly accounting for bias makes a difference. The mean WTP for all respondents who said “yes” responses is 3.8 times the mean WTP for respondents who said “yes” and are definitely sure.

7. Estimating Individual, Private Market Value: The Gain in Earnings

We estimate the individual returns to community college degrees compared with a high school diploma for the residents of Kentucky. Although there has been extensive research on the individual returns to higher education, in general that research focuses 
almost exclusively on the nation as a whole. In order to measure the private benefits of expanding KCTCS to Kentucky residents, we use two approaches.

In our first approach, we use data for Kentucky residents from the 2000 U.S. Decennial Census. We use these data to estimate the increase in work-life earnings of individuals associated with increased education levels, with a particular focus on the gains from attending a college without earning a degree and from obtaining an associate’s degree. Specifically, we calculate discounted present value of lifetime earnings levels for each education level, taking into account tuition cost of the education and foregone earnings. $^{15}$

Before calculating lifetime earnings levels, we start by estimating a standard Mincer (1974) earnings equation:

$$
\ln Y_{i}=\alpha_{i}+\beta S_{i}+\gamma X_{i}+\varepsilon_{i}
$$

where $\ln \mathrm{Y}$ is the natural logarithm of annual earnings, $\mathrm{S}$ is a set of dummy variables for highest degree, $\mathrm{X}$ is a set of demographic characteristics such as potential experience, race/ethnicity, and marital status, $\varepsilon$ is the unobserved, error term, and $i$ denotes an individual. Among the variables included in $\mathrm{S}$ is a dummy variable for individuals who have completed an associate’s degree as their highest level of education.

When estimating equation (1) we restrict our sample to individuals ages 20 to 60 who live in Kentucky and who have positive work earnings for 1999 for a total of approximately 76,000 observations. We also estimate the model separately for men and women. Table 5 contains the results from our estimation. The coefficients for education levels can be interpreted as the percentage increase in annual earnings relative to

\footnotetext{
${ }^{15}$ In order to be consistent with our estimates of total social value, all dollar amounts have been converted to 2007 dollars using the CPI-U.
} 
individuals with a high school degree or less, the omitted group in the regression. The table shows that males with an associate's degree have annual earnings that are 24.3 percent higher than high school graduates. Females with associate’s degrees receive an earnings premium of 43.8 percent over high school graduates. The finding that women experience a larger percentage increase in earnings than men is consistent with previous results in the literature looking at returns to an associate’s degree (Kane and Rouse, 1995).

In our second approach, we use administrative data from the Kentucky Community and Technical College System (KCTCS) matched with quarterly earnings data from the Kentucky unemployment insurance program. We have data for the cohort of approximately 22,000 students who entered KCTCS from summer 2002 to spring 2003. The advantage of these administrative data is that, in addition to having information on receipt of an associate's degree, we also have data on the receipt of a diploma or certificate - information not available in Census data. ${ }^{16}$ Diplomas typically require a year or more of full-time study, and they cover a broad range of areas. Certificates usually require less coursework, and they often target specific employers. The private returns to diplomas and certificates cannot be estimated with the Census data. Because the KCTCS data contain only individuals who enrolled in KCTCS, we estimate the effect of an award by comparing the quarterly earnings of KCTCS students after they left KCTCS with the quarterly earnings of the same KCTCS students prior to enrolling in KCTCS; we also compare students who received an award with students who

\footnotetext{
${ }^{16}$ According to our administrative data from the KCTCS, more than half of the highest degrees awarded are certificates and diplomas.
} 
attended KCTCS but did not receive an award. More formally, we estimate a student fixed effects earnings model as shown in equation (2):

$$
\ln Y_{\text {it }}=\beta S_{i t}+\gamma X_{i t}+\eta_{i}+\tau_{t}+\varepsilon_{i t}
$$

In this equation, $\ln \mathrm{Y}$ is the natural logarithm of quarterly earnings, $i$ denotes an individual, and $t$ denotes the time (quarter). S contains three dummy variables which are equal to one for the highest award received in the current time period (quarter). The associate's degree is the highest award offered by KCTCS; diploma is the secondhighest; and certificate is the third-highest. $\mathrm{X}$ is a set of time-varying student characteristics such as age, age-squared, and interactions with nonwhite, and $\eta$ and $\tau$ are student and time fixed effects. ${ }^{17}$

The results from estimation of equation (2) are presented in Table 6. In this table, the coefficients for education levels can be interpreted as the percentage increase in quarterly earnings relative to quarterly earnings without a degree, diploma, or certificate. The table shows that males with an associate's degree have a quarterly earnings premium of 10.5 percent, and females with associate's degrees receive a quarterly earnings premium of 31.9 percent. For diplomas, the increase in quarterly earnings is 6.7 percent for men and 30.0 percent for women. For men, receiving a certificate has no statistically significant impact on earnings, but for women receiving a certificate is associated with an increase of 7.2 percent. Again, we find higher returns for women than for men.

We convert the educational returns presented in Tables 5 and 6 to lifetime earnings amounts to facilitate comparison with our estimates of the total social value of KCTCS. First, we calculate the predicted annual earnings for high school graduates and recipients of certificates, diplomas, and associate's degrees using the estimates from

\footnotetext{
${ }^{17}$ For more detail on the data and estimation, see Jepsen, Troske and Coomes (2008).
} 
equations (1) and (2). We calculate annual earnings for each age from 18 to 80. Then, we multiply the predicted earnings for each year by the likelihood of being employed with that level of experience. For each age, this likelihood is the survival rate (the probability of living to that age) multiplied by the probability of being employed conditional on living to that age. The lifetime earnings for each education level are simply the sum of predicted discounted real earnings at each age. Earnings are discounted at an annual rate of 2.8 percent, the real rate specified by the Office of Management and Budget for long-term discounting (Federal Register, 2008, page 5599).

Table 7 shows earnings returns to an associate's degree compared to a high school degree in Kentucky assuming educational attainment at age $20{ }^{18}$ The returns are calculated separately for men and women. Estimated lifetime returns to an associate's degree vary by data source. For women, the lifetime return based on Census data is approximately $\$ 92,000$ compared with approximately $\$ 96,000$ based on KCTCS data. ${ }^{19}$ Similarly, the estimated benefits for men are $\$ 64,000$ from the Census data and $\$ 47,000$ from the KCTCS data. . Therefore, we expect to find larger lifetime earnings estimates in the Census data compared with the KCTCS data. The lifetime returns - based on KCTCS data - for diplomas are about $\$ 92,000$ for women and $\$ 27,000$ for men. For certificates, the returns are roughly $\$ 14,000$ for women and negative $\$ 15,000$ for men, although the result for men is statistically insignificant at the 10 percent level. All other results are statistically significant at the one percent level. The results, particularly for

\footnotetext{
${ }^{18}$ Our estimates of the value of a 10 percent expansion of the KCTCS system, however, are based on the distribution of ages when degrees, diplomas, and certificates are actually earned.

${ }^{19}$ The lifetime earnings estimates in Table 7 are based on the estimated values of earnings from equations (1) and (2). These estimated values are based on the coefficients for age (and age squared), highest degree, and the constant term, and all these coefficients differ between the Census and KCTCS data. Differences in the coefficients for age and the constant term explain why the estimated lifetime earnings returns to an associate's degree is higher for women in KCTCS data than for women in the Census data even though the coefficient for associate's degree is lower in the KCTCS data than in the Census data.
} 
the KCTCS data, show a dramatically larger increase in earnings for women compared with men. Jepsen, Troske, and Coomes (2008) show that much of this difference can be explained by differences in field of study. Still, these results are not surprising given the differences in regression coefficients by gender in Tables 5 and 6.

8. Comparing the Total Social Value to Individual, Private Values - the Externality From the contingent valuation survey results we estimate the willingness to pay for KCTCS. We estimate that the average household in Kentucky is willing to pay \$56 for a 10 percent expansion of KCTCS and the total social value for all Kentucky households is \$92.1 million. These estimates are based on counting as “yes” only those “yes” responses for which respondents are definitely sure. The estimate includes both those market and non-market benefits Kentuckians receive individually as well as benefits to all society in the form of reduced crime, healthier citizens, better public decision making, and greater productivity of other workers.

By comparing the estimated increase in individual returns from expanding the KCTCS system with the total returns that would result from expanding the system, we estimate what percentage of the increased benefits would accrue directly to the additional students that would attend a KCTCS college if the system were expanded and how much of the increased benefits would accrue to all Kentuckians regardless of whether or not they attended a KCTCS college.

KCTCS awarded 6,480 Associate’s Degrees in 2006-2007, so a 10 percent increase in KCTCS degrees would result in 648 additional people obtaining an 
associate's degree in a year. ${ }^{20}$ Of the degrees awarded in 2006-2007, 64 percent were awarded to females and 36 percent were awarded to males. Assuming that the same percentages hold for a 10 percent expansion, the 648 additional degrees would be broken down into 435 degrees for women and 213 degrees for men. Using a similar assumption for diplomas and certificates leads to an estimated increase of 145 diplomas for women and 85 diplomas for men, along with 689 certificates for women and 530 certificates for men.

We assume that these individuals will receive their degrees, diplomas, and certificates at the same ages at which recent KCTCS graduates have received their degrees. In other words, we use the distribution of ages of the graduates in the KCTCS administrative data rather than assuming that, say, individuals who earn their associate's degrees begin work at age 20. In fact, the average age for associate's degree recipients is 30. Based on age of degree receipt, we then calculate each person's lifetime earnings by summing up the returns for each age from degree/diploma/certificate receipt until 80 years of age, based on calculations using the Decennial Census reported in the previous section. The estimates of aggregate earnings returns based on these calculations are shown in Table 8. Also shown are the effects of work and survival probabilities. If we sum the individual returns for these individuals, we find that the estimated increase in individual returns from a 10 percent expansion of KCTCS is approximately \$61 million based on Census data and \$48 million based on KCTCS data. Despite the different assumptions of the two estimates, the more narrowly defined long run estimates from the

\footnotetext{
${ }^{20}$ We assume that an expansion of 10 percent would increase output by 10 percent because we do not have a strong argument for an alternative. Expansion of programs could induce some current students to switch to new programs rather than attracting more students. Switching would lead us to overestimate the gain. However, to the extent that the expansion leads to better matches with students and jobs, then there will be greater productivity that will offset some of the overestimate.
} 
Census are only about 26 percent higher than the more broadly defined short run estimates of the private benefits of a KCTCS expansion.

The estimated private return for the Census data contains no controls for occupation. Because a worker's occupation varies with education level, we also estimate the private returns with Census data that include controls for occupation, and find that the private returns fall from $\$ 61$ million to $\$ 49$ million. ${ }^{21}$ This finding suggests that part of the private return of an associate's degree operates through changes in occupation.

The predicted private returns from our preferred specification using Census data (not controlling for occupation) are smaller than the point estimate of the total benefits produced by expanding KCTCS (\$92.1 million). Both the Census and KCTCS estimates (\$61.2 million and \$48.4 million) are below the 90 percent confidence interval (\$68.9 million to $\$ 115.4$ million) of our estimate of total social value. Nonetheless, our point estimate of the total social value of expanding KCTCS by 10 percent is approximately 51 percent greater than the private returns estimated using Census data and approximately 90 percent greater than private returns estimated using KCTCS data. Our estimates of the private returns depend on the discount rate, and Table A2 in the Appendix gives estimates using discount rates of 1 percent and 4 percent along with 2.8 percent. The estimates for a discount rate of 1 percent for Census (\$88.8 million) and KCTCS (\$74.2 million) are greater than the lower bound of our 90 percent confidence interval for total social returns (\$68.9 million), but they are less than the point estimate of $\$ 92.1$ million. Our estimates suggest that the education externalities in the form of enhanced quality of life and productivity are substantial.

\footnotetext{
${ }^{21}$ The results are available upon request. The KCTCS administrative data do not contain occupation information.
} 
9. Wages, Area-wide Education, and OLS Estimates of the Education Externality As we discuss in Section 2, several attempts have been made to estimate the social returns to education by measuring the effect of education spillovers on individual labor-market returns. In other words, how much higher are a given worker's earnings if he or she lives in an area with more educated individuals? This model can be illustrated by the following equation:

(3) $\ln Y_{i}=\alpha_{i}+\beta S_{i}+\gamma X_{i}+\delta A S_{i}+\varepsilon_{i}$ where $\mathrm{Y}, \mathrm{S}$, and $\mathrm{X}$ are defined as in equation (1) and $\mathrm{AS}_{\mathrm{i}}$ measures the level of schooling in the area. Examples of attempts to estimate equation (3) can be found in Rauch (1993), Acemoglu and Angrist (2000), and Moretti (2004a), as well as the reviews by Moretti (2004b) and Lange and Topel (2006).

As we discuss above, one of the problems with estimating equation (3) is that there may be some unobserved factor about an area that is correlated with the average schooling in an area leading to a correlation between $\mathrm{AS}_{\mathrm{i}}$ and $\varepsilon_{\mathrm{i}}$ and a biased estimate of $\delta$. In their estimates both Acemoglu and Angrist (2000) and Moretti (2004a) try to adjust for this bias using instrumental variables although Lange and Topel (2006) have questioned the validity of their instruments. Given their concerns, and the lack of sufficient variation in the available instruments, we do not attempt to adjust for any possible bias in our estimates. We present them only to allow a comparison between our estimates of $\delta$ found using Kentucky data with the estimates found by previous researchers. 
Table 9 contains the results from a model that estimates spillover effects using the data from the 2000 Decennial Census for Kentucky. ${ }^{22}$ An area is measured as one of the 30 Public Use Microdata Areas (PUMA) in Kentucky (see Blomquist et al. (2007) for details). ${ }^{23}$ For consistency with previous results, estimates are provided separately for men and for women. So that we can easily compare our estimates with previous estimates, we measure $A S_{i}$ three ways. In columns (1) and (4) $\mathrm{AS}_{\mathrm{i}}$ is measured as the average years of schooling among residents in an area, which corresponds to the measures used by Rausch (1993) and Acemoglu and Angrist (2000). ${ }^{24}$ In columns (2) and (5) we measure $\mathrm{AS}_{\mathrm{i}}$ as the percentage of individuals in the area with at least a bachelor's degree. In columns (3) and (6) we measure $\mathrm{AS}_{\mathrm{i}}$ as the percentage of with at least an associate’s degree.

We find a strong association between the level of schooling in an area and an individual's earnings for all three measures. Looking at the results in columns (1) and (4) we see that a one year increase in the average education in an area is associated with an 8 percent increase in earnings for both men and women. This is slightly higher than Rausch's (1993) estimates of 2.8 to 5.1 percent, but corresponds closely to the OLS estimate of 7.3 percent reported in Acemoglu and Angrist (2000). In columns (2) and (4) we see that a one percent increase in the percent of residents with a college degree is associated with a 0.7 percent increase in earnings, which is slightly below Moretti's (2004a) estimate of 1 percent. So, our estimates are similar to estimates found elsewhere in the literature.

\footnotetext{
${ }^{22}$ Because the regional education level does not vary within student in the KCTCS administrative data, the spillover effect is contained in the student fixed effect. Therefore, we do not estimate spillover effects with the KCTCS data.

${ }^{23}$ The PUMAs in Kentucky have a universe population of between 100,000 and 200,000 persons. The sample size after filtering out individuals less than 25 years of age varies from between 3,000 and 8,000.

${ }^{24}$ We compute the average years of schooling for all residents 16 years old and older.
} 
Next, we compare the estimates of the effect of individual education on earnings results reported in Table 5 with the result in Table 9 when we include measures of educational attainment in an area. The results in column (3) and (6) in Table 9 show that a one percentage-point increase in the percentage of individuals with at least an associate's degree is associated with a 0.7 percent increase in earnings. In addition to these education spillovers, a person who receives an associate's degree receives a private return of approximately 21 percent for men and 41 percent for women (according to Table 9.) These estimated private returns are slightly lower that the private returns reported in Table 5 (24 percent and 44 percent). This pattern of results suggests that part of the private return in Table 5 is actually an education spillover.

\section{Comparing Benefits to Costs}

In order to get an idea of the magnitude of this social value of education number, it is useful to compare the value of a 10 percent expansion to the costs of a 10 percent expansion. Information on costs was taken from the KCTCS budget. The revised 20062007 fiscal year budget shows that total expenditures for operating KCTCS were \$633 million. If we assumed that the cost of a 10 percent expansion would be equal to 10 percent of current operating costs, then an estimate of the total cost of the expansion is approximately $\$ 63$ million. Comparing the our estimate of the total value of a 10 percent expansion (\$92.1 million) with the total costs of a 10 percent expansion indicates that Kentuckians value the expansion by an amount that is about 1.5 times what it would cost 
to expand the system. The cost is also below the 90 percent confidence interval for the total social value (\$68.9 million, $\$ 115.4$ million). ${ }^{25}$

\section{Conclusions and Discussion}

A great deal of evidence strongly supports the existence of substantial individual, private returns to education including higher education. In this paper we have focused on education offered by community and technical colleges about which previous research offers have less evidence than university education. Based on 2000 Census data we estimate that the increase in lifetime earnings for an associate’s degree over only a high school education for an individual who is 20 is approximately $\$ 64,000$ for men and \$92,000 for women. Based on the KCTCS data for the 2002-2003 cohort and for a shorter period of earnings growth, we estimate that the increase in lifetime earnings over high school education is roughly $\$ 47,000$ for men and $\$ 96,000$ for women. These individual, private gains in earnings are sizable. We also find a positive relationship between an individual's earnings and the region-wide percentage with an associate's degree or more. A one percentage point increase in residents with at least an associate's degree in a Census Public Use Microdata Area is associated with an increase in average wages by about 0.7 percent. However, these increases do not necessarily measure education externalities because of possible, and even likely, geographic sorting of

\footnotetext{
${ }^{25}$ This increase in the system ignores any increase in buildings and other infrastructure costs since we are assuming that KCTCS could expand the number of students they serve without building any new buildings. According to KCTCS officials, the current value of KCTCS buildings is \$401 million so a 10 percent increase in the number of buildings would be $\$ 40$ million. If we add this to the increase in operating expenditures, the benefits to expanding the system by 10 percent are about equal to the costs of expanding the system.
} 
individuals by ability that is correlated with education. The estimates are, however, within the range (0.6 to 1.2 percent) reported by Moretti (2004a).

To estimate the social value of education the typical approach is to use instrumental variables. In contrast, we offer a first attempt at an alternative method. We estimate the total social value of a 10 percent expansion of KCTCS using a contingent valuation survey. The education externality is the difference between total social value and the individual, private gain in earnings associated with a 10 percent expansion of KCTCS. Our estimate of the spillover benefit depends on the adjustment we make for hypothetical bias in contingent valuation. The estimates in which we have the most confidence are based on survey respondents who are definitely sure they would vote for a referendum that expands KCTCS and has a tax of a specified amount tied to it. Our preferred estimate of the total social value exceeds our estimate of private earnings gain by approximately 50 percent for the long run estimate from Census data and more (90 percent) for the short run estimate from KCTCS data.

The estimates of private earnings gain from the Census and KCTCS data may be too small. The Census estimate does not include the private returns to diplomas and certificates, and the KCTCS estimate is based on short-run rather than long-run labor market returns. On the other hand, we suspect that these estimates of the individual returns may be too large because the estimated returns are based on individuals who already have received an associate's degree, diploma, or certificate. Presumably the additional people who would receive a degree, diploma, or certificate if KCTCS were expanded would have a lower return than those who would be obtaining such outcomes without an expansion. Caution should be exercised in making inferences from our 
relatively small sample for one state, Kentucky. Educational attainment is lower in Kentucky and a larger sample representative of the U.S. might be expected to produce different results. We suspect the social value of expanding community and technical colleges might be lower in the rest of the nation where a larger share of the population has at least an associate's degree.

Our estimate of the total social value has the advantage that it captures all productivity and quality of life externalities. Our estimate of the education externality may be too large, however, because of private, non-market benefits that accrue to individuals. As discussed in Becker and Murphy (2007) one of the advantages of additional education is that it raises individual productivity in household production. Unfortunately, as far we are aware, there are no current estimates of the private nonmarket gains in productivity due to education. As a consequence we are unable to cleanly separate these private gains from the total social value. ${ }^{26}$ Being able to separate these private gains from the social gain would be useful, but given the size of our estimated total social value, it seems clear that a substantial portion of the total accrues to society as a whole and not only to the individual.

Our estimates of the social value are a large percentage of the private earnings return, but they are not implausible. For example, Lochner and Moretti (2004) estimate that the size of the external effect of education through the single channel of reducing crime is 14 to 26 percent of the private return to schooling. Our estimate could include the value of higher education as an in-kind transfer program in addition to the external effects already discussed such as productivity spillovers, less crime, and better government. Educational subsidies can be treated as a means of changing the income

\footnotetext{
${ }^{26}$ The only study we are aware of Michael (1973).
} 
distribution, for example see Hanushek et al. (2003). Presumably our estimate of total social value captures this value also. The finding that respondents older than 50 are willing to pay more for the KCTCS expansion is consistent with valuing spillovers or transfers or both.

Optimal financing of higher education depends on the existence and size of positive education externalities. If all the returns are to the individual in the market or in the household, then optimal financing likely only includes provision of unsubsidized loans. Our estimates suggest substantial external benefits for expansion of community and technical college education. These gains in quality of life or productivity, or as a transfer, suggest financing the expansion through unsubsidized loans would be inefficient. Hilmer (1998) provides evidence that higher fees at community colleges reduce the probability of enrollment. Subsidized loans that essentially reduce fees might be an efficient policy given our finding of substantial spillovers. Whether findings would be the same for a national total social value study or a total social value study of higher education in the form of bachelor's degrees is worth exploring. 


\section{References}

Acemoglu, Daron and Joshua Angrist. 2000. "How Large Are the Social Returns to Education? Evidence from Compulsory Schooling Laws” In NBER Macroannual 15 eds., B.S. Bernanke and K. Rogoff. Cambridge, MA, MIT Press: 9-59.

Arrow, Kenneth J., Robert Solow, Paul Portney, Edward E. Leamer, Roy Radner, and Howard Schuman. 1993. Report on the NOAA Panel on Contingent Valuation. In Federal Register 58:10, Washington, D.C.: (January 15): 4602-4614.

Becker. Gary S. and Kevin M. Murphy. 2007. "Education and Consumption: The Effects of Education in the Household Compared to the Marketplace.” Journal of Human Capital 1, 1: 9-35.

Bergstrom, Theodore C., Daniel L. Rubinfeld, and Perry Shapiro. 1982. "Micro-Based Estimates of Demand Functions for Local School Expenditures." Econometrica 50, no. 5 (September): 1183-205.

Board of Governors of the Federal Reserve System. 2007. H.15 Selected Interest Rates. Federal Reserve Statistical Release, http://www.federalreserve.gov/releases/h15/data.htm.

Blomquist, Glenn C., Paul A. Coomes, Christopher Jepsen, Brandon Koford, Barry Kornstein, and Kenneth R. Troske. 2007. The Individual, Regional, and State Economic Impacts of Kentucky Community and Technical Colleges. Center for Business and Economic Research, University of Kentucky, http://cber.uky.edu/pdf/CBER_UL_KCTCSReport_10-2007.pdf

Blumenschein, Karen, Glenn C. Blomquist, Magnus Johannesson, Nancy Horn, and Patricia R. Freeman. 2008. "Eliciting Willingness to Pay without Bias: Evidence from a Field Experiment” The Economic Journal 118, 525: 114-137.

Blumenschein, Karen, Magnus Johannesson, Glenn Blomquist, Bengt Liljas, and Richard O'Conor. 1997. "Hypothetical versus Real Payments in Vickery Auctions" Economics Letters 56: 177-180.

Blumenschein, Karen, Magnus Johannesson, Glenn Blomquist, Bengt Liljas, and Richard O'Conor. 1998. "Experimental Results on Expressed Certainty and Hypothetical Bias in Contingent Valuation” Southern Economic Journal 65, 1: 169-177.

Card, David. 1999. “The Causal Effect of Education on Earnings” In The Handbook of Labor Economics, Vol. 3A, eds. Orley C. Ashenfelter and David Card. New York: Elsevier Science, North-Holland: 1801-1863.

Carson, Richard T. 2000. “Contingent Valuation: A User's Guide” Environmental Science and Technology 34, 8: 1413-1418. 
Carson, Richard T. and Theodore Groves. 2007. "Incentives and Informational Properties of Preference Questions” Environmental and Resource Economics 37,1 (May): 181-210.

Cawley, John. 2006. "Contingent Valuation Analysis of Willingness to Pay to Reduce Childhood Obesity." National Bureau of Economic Research Working Paper Series No. 12510 (September).

Champ, Patricia A., and Richard C. Bishop. 2001. "Donation Payment Mechanisms and Contingent Valuation: An Empirical Study of Hypothetical Bias” Environmental and Resource Economics 19, 4: 383-402.

College Board. 2008. Winning the Skills Race and Strengthening America's Middle Class: An Action Agenda for Community Colleges. New York: College Board. http://professionals.collegeboard.com/profdownload/winning_the_skills_race.pdf

Cummings, Ronald G., and Laura O. Taylor. 1999. “Unbiased Value Estimates for Environmental Goods: A Cheap Talk Design for the Contingent Valuation Method” American Economic Review 89, 3: 649-665.

Cutler, David M., and Adriana Lleras-Muney. 2008. "Education and Health: Evaluating Theories and Evidence” In Making Americans Healthier: Social and Economic Policy as Health Policy, eds., J. House, R. Schoeni, G. Kaplan, and H. Pollack. New York: Russell Sage Foundation.

Dee, Thomas S. 2004. “Are There Civic Returns to Education?” Journal of Public Economics 88: 1697-1720.

De Fraja, Gianni. 2008. "Market and Public Provision in the Presence of Human Capital Externalities” Journal of Public Economics 92, 5-6 (June): 962-985.

Drago, Robert, David Costanza, Robert Caplan, Tanya Brubaker, Darnell Cloud, Naomi Harris, Russell Kashian, and T. Lynn Riggs. 2001. "The Willingness-to-Pay for Work/Family Policies: A Study of Teachers." Industrial and Labor Relations Review 55, no. 1 (October): 22-41.

Dyke, Andrew, Carolyn J. Heinrich, Peter R. Mueser, Kenneth R. Troske, and KyungSeong Jeon. 2006. "The Effects of Welfare-to-Work Program Activities on Labor Market Outcomes” Journal of Labor Economics 24, 3: 567-607.

Epstein, Richard A. 2003. "The Regrettable Necessity of Contingent Valuation." Journal of Cultural Economics 27, no. 3 (November): 259-74.

Escobar, Colette M., W. Steven Barnett, and John E. Keith. 1988. "A Contingent Valuation Approach to Measuring the Benefits of Preschool Education." Educational Evaluation and Policy Analysis 10, no. 1 (Spring): 13-22. 
Federal Register. 2008. "Discount Rates for Cost-Effectiveness Analysis of Federal Programs” 73, 20 (January 30): 5599.

Friedman, Milton. 1962. Capitalism and Freedom. Chicago, University of Chicago Press.

Glaeser, E. and R. Saks. 2006. “Corruption in America” Journal of Public Economics 90, 6-7: 1053-1072.

Grossman, Michael. 2006. "Education and Nonmarket Outcomes” In The Handbook of Economics of Education, Vol. 1, eds. Eric Hanushek and Finis Welch. Amsterdam: Elsevier, North-Holland: 577-633.

Harrison, Glenn W. 2006. “Experimental Evidence on Alternative Environmental Valuation Methods” Environmental and Resource Economics, 34, 1: 125-162.

Heckman, James J., Lance J. Lochner and Petra E. Todd. 2006. “Earnings Functions, Rates of Return and Treatment Effects: The Mincer Equation and Beyond” In The Handbook of Economics of Education, Vol. 1, eds. Eric Hanushek and Finis Welch. Amsterdam: Elsevier, North-Holland: 307-458.

Hilmer, Michael J. 1998. "Post-secondary Fees and the Decision to Attend a University or a Community College” Journal of Public Economics 67: 329-348.

Jacobson, Louis S., Robert J. LaLonde, and Daniel G. Sullivan. 2005a. “Estimating the Returns to Community College Schooling for Displaced Workers” Journal of Econometrics, 125,1-2: 271-304.

Jacobson, Louis S., Robert J. LaLonde, and Daniel G. Sullivan. 2005b. “The Impact of Community College Retraining on Older Displaced Workers: Should We Teach Old Dogs New Tricks?” Industrial and Labor Relations Review, 58, 3: 398-415.

Jepsen, Christopher, Kenneth R. Troske, and Paul A. Coomes. 2008. “The Labor Market Returns for Community College Degrees, Diplomas, and Certificates” University of Kentucky Working Paper.

Johansson, P-O. (1995) Evaluating Health Risks: An Economic Approach. Cambridge: Cambridge University Press

Kane, Thomas J., and Cecilia Elena Rouse. 1995. "Labor Market Returns to Two-Year and Four-Year Schools” American Economic Review 85, 3: 600-614.

Kenkel, Donald S. 1991. "Health Behavior, Health Knowledge, and Schooling” Journal of Political Economy 99, 2: 287-305.

Lange, Fabian, and Robert Topel. 2006. “The Social Value of Education and Human Capital” In The Handbook of Economics of Education, Vol. 1, eds. Eric Hanushek and Finis Welch. Amsterdam: Elsevier, North-Holland: 459-509. 
Lankford, R. Hamilton. 1985. "Efficiency and Equity in the Provision of Public Education." The Review of Economics and Statistics 67, no. 1 (February): 70-80.

List, John A. and Craig A. Gallet. 2001. "What Experimental Protocol Influence Disparities between Actual and Hypothetical Stated Values" Environmental and Resource Economics 20: 241-254.

Little, Joseph and Robert Berrens. 2004. "Explaining Disparities between Actual and Hypothetical Stated Values: Further Investigation Using Meta-analysis" Economics Bulletin, 3,6: 1-13.

Lochner, Lance, and Enrico Moretti. 2004. "The Effect of Education on Crime: Evidence from Prison Inmates, Arrests, and Self-Reports” American Economic Review, 94,1: 155-189.

Marcotte, Dave E., Thomas Bailey, Carey Borkoski, and Greg S. Kienzl. 2005. "The Returns from a Community College Education: Evidence from the National Educational Longitudinal Survey” Educational Evaluation and Policy Analysis, 27, 2: 157-175.

McMahon, Walter W. 2007. "An Analysis of Education Externalities with Applications to Development in the Deep South" Contemporary Economic Policy 25, 3: 459482.

Michael, Robert T. 1973. "Education in Non-Market Production" Journal of Political Economy, 81, 2: S128-S164.

Mincer, Jacob. 1974. Schooling, Experience, and Earnings. New York: Columbia University Press.

Milligan, Kevin, Enrico Moretti, and Philip Oreopoulos. 2004. "Does Education Improve Citizenship? Evidence from the United States and the United Kingdom" Journal of Public Economics, 88, 9-10:1667-1695.

Moretti, Enrico. 2004a. "Estimating the Social Return to Higher Education: Evidence from Longitudinal and Repeated Cross-Sectional Data" Journal of Econometrics, 121,1-2: 175-212.

Moretti, Enrico. 2004b. "Human Capital Externalities in Cities” In V. Henderson and J.F. Thisse, eds., Handbook of Urban and Regional Economics, vol. 4 Amsterdam: North Holland.

Poe, Gregory L., Jeremy E. Clark, Daniel Rondeau, and William D. Schulze. 2002. "Provision Point Mechanisms and Field Validity Tests of Contingent Valuation" Environmental and Resource Economics 23, 1: 105-131.

Rauch, James. 1993. "Productivity Gains from Geographic Concentration in Cities" Journal of Urban Economics 34, 380-400. 
Rosenthal, Stuart S. and William C. Strange. 2008. "The Attenuation of Human Capital Spillovers” Journal of Urban Economics 64, 2 (September): 373-389.

Rubinfeld, Daniel L. 1977. "Voting in a Local School Election: A Micro Analysis." The Review of Economics and Statistics 59, no. 1 (February): 30-42.

Siegfried, John J., Allen R. Sanderson and Peter McHenry. 2007. “The Economic Impact of Colleges and Universities” Economics of Education Review 26: 546-558.

Shapiro, Jesse M. 2006. "Smart Cities: Quality of Life, Productivity, and the Growth Effects of Human Capital” The Review of Economics and Statistics, 88, 2: 324335.

Stair, Anthony, Terance J. Rephann, and Matt Heberling. 2006. "Demand for Public Education: Evidence from a Rural School District." Economics of Education Review 25, no. 5 (October): 521-31.

U.S. Bureau of Census. 2007. American Community Survey, Public Use Microdata Sample Files. Population and Housing Records.

U.S. Department of Education, National Center for Education Statistics. 2001. Digest of Education Statistics Tables and Figures. Washington, DC: http://nces.ed.gov/programs/digest/d01/dt202.asp.

U.S. National Center for Health Statistics. 2006. National Vital Statistics Reports. 54, no. 14, April 19, 2006 (as revised March 28, 2007), http://www.cdc.gov/nchs/data/nvsr/nvsr54/nvsr54_14.pdf.: 10-13.

Wheeler, Christopher H. 2008. "Human Capital Externalities and Adult Mortality in the U.S.” Federal Reserve Bank of St. Louis Working Paper 2007-045C. St. Louis, MO.

Wolfe, Barbara L. and Robert H. Haveman. 2002. "Social and Nonmarket Benefits from Education in an Advanced Economy” In Yolanda K. Kodrzycki, ed. Education in the 21st Century: Meeting the Challenges of a Changing World. Federal Reserve Bank of Boston. http://www.bos.frb.org/economic/conf/conf47/conf47g.pdf

Yamarik, Steven J. 2008. “Estimating Returns to Schooling from State-Level Data: A Macro-Mincerian Approach.” The B.E. Journal of Macroeconomics, 8,1 (Contributions), Article 23. http://www.bepress.com/bejm/vol8/iss1/art23 
Table 1. Demographics of KCTCS Survey vs. American Community Survey 2007 for Kentucky

\begin{tabular}{|c|c|c|c|c|c|c|}
\hline & & $\begin{array}{c}\text { Web-based } \\
\text { Sample } \\
\end{array}$ & $\begin{array}{c}\text { Mail- } \\
\text { based } \\
\text { Sample }\end{array}$ & $\begin{array}{c}\text { P-Value: } \\
\text { Web vs. Mail } \\
\end{array}$ & $\begin{array}{c}\text { Total } \\
\text { Sample }\end{array}$ & $\begin{array}{c}\text { American } \\
\text { Community } \\
\text { Survey } 2007 \\
\end{array}$ \\
\hline Gender & Female & $52.50 \%$ & $53.20 \%$ & 0.899 & $53.14 \%$ & $51.93 \%$ \\
\hline \multirow[t]{5}{*}{ Age } & $18-29$ & $21.54 \%$ & $19.96 \%$ & 0.553 & $20.12 \%$ & $21.69 \%$ \\
\hline & $30-39$ & $10.40 \%$ & $15.17 \%$ & 0.15 & $14.69 \%$ & $17.24 \%$ \\
\hline & $40-49$ & $25.96 \%$ & $19.43 \%$ & 0.136 & $20.08 \%$ & $19.56 \%$ \\
\hline & $50-64$ & $28.49 \%$ & $28.25 \%$ & 0.594 & $28.27 \%$ & $24.68 \%$ \\
\hline & 65 or over & $13.61 \%$ & $17.20 \%$ & 0.471 & $16.84 \%$ & $16.83 \%$ \\
\hline Race & White & $90.45 \%$ & $89.39 \%$ & 0.791 & $89.49 \%$ & $90.37 \%$ \\
\hline \multirow[t]{6}{*}{ Education } & Less than High School Diploma & $8.67 \%$ & $17.07 \%$ & 0.023 & $16.26 \%$ & $19.58 \%$ \\
\hline & High School Diploma or Equivalent & $45.29 \%$ & $36.74 \%$ & 0.132 & $37.56 \%$ & $35.19 \%$ \\
\hline & Some College & $15.85 \%$ & $18.65 \%$ & 0.378 & $18.38 \%$ & $20.71 \%$ \\
\hline & Associate’s Degree & $10.45 \%$ & $8.13 \%$ & 0.585 & $8.35 \%$ & $6.01 \%$ \\
\hline & Bachelor’s Degree & $11.23 \%$ & $11.21 \%$ & 0.99 & $11.21 \%$ & $11.43 \%$ \\
\hline & Master’s Degree or Beyond & $8.51 \%$ & $8.20 \%$ & 0.086 & $8.23 \%$ & $7.08 \%$ \\
\hline \multirow[t]{5}{*}{ Household Income } & Under $\$ 25,000$ & $36.39 \%$ & $36.76 \%$ & 0.622 & $36.72 \%$ & $32.31 \%$ \\
\hline & $\$ 25,000$ - \$39,999 & $19.72 \%$ & $17.77 \%$ & 0.414 & $17.97 \%$ & $17.91 \%$ \\
\hline & $\$ 40,000-\$ 59,999$ & $22.09 \%$ & $18.42 \%$ & 0.247 & $18.79 \%$ & $17.89 \%$ \\
\hline & $\$ 60,000$ - \$99999 & $16.97 \%$ & $18.82 \%$ & 0.952 & $18.63 \%$ & $19.96 \%$ \\
\hline & $\$ 100,000$ or more & $4.82 \%$ & $8.23 \%$ & 0.062 & $7.89 \%$ & $11.92 \%$ \\
\hline
\end{tabular}

Note: Both the KCTCS Survey statistics and the American Community Survey statistics are for those individuals 18 years old or over. The sample size for each variable in the web-based sample is 275. The total sample size is 2,892 for Gender, 2,827 for Age, 2,877 for Race, 2,867 for Education, and 2,725 for Household Income. 
Table 2. Definitions of Variables and Summary Statistics

\begin{tabular}{|c|c|c|}
\hline Variables & Mean & Description \\
\hline Tax & $\begin{array}{c}162.2 \\
{[166.84]}\end{array}$ & $\begin{array}{l}\text { Dollar amount individual would pay for change in } \\
\text { KCTCS in } 2007 \text { dollars. Amounts were one of eight } \\
\text { amounts: } 25 \text { (21\%), } 75 \text { (21\%), } 100 \text { (3\%), } 125 \text { (2\%), } \\
150 \text { (21\%), } 200 \text { (2\%), } 250(18 \%), 400(14 \%) .\end{array}$ \\
\hline Income $\$ 25-39 \mathrm{~K}$ & 0.22 & $\begin{array}{l}1 \text { if } \$ 25,000 \leq \text { household income } \leq \$ 39,999,0 \\
\text { otherwise }\end{array}$ \\
\hline Income $\$ 40-59 \mathrm{~K}$ & 0.17 & $\begin{array}{l}1 \text { if } \$ 40,000 \leq \text { household income } \leq \$ 59,999,0 \\
\text { otherwise }\end{array}$ \\
\hline Income $\$ 60-99 \mathrm{~K}$ & 0.16 & $\begin{array}{l}1 \text { if } \$ 60,000 \leq \text { household income } \leq \$ 99,999,0 \\
\text { otherwise }\end{array}$ \\
\hline Income $>\$ 100 \mathrm{~K}$ & 0.08 & 1 if household income $\geq \$ 100,000,0$ otherwise \\
\hline Income Missing & 0.05 & $\begin{array}{l}1 \text { if no response to household income question, } 0 \\
\text { otherwise }\end{array}$ \\
\hline High School Diploma & 0.35 & $\begin{array}{l}1 \text { if earned high school diploma or equivalent, } 0 \\
\text { otherwise }\end{array}$ \\
\hline Some College & 0.2 & 1 if attended some college, 0 otherwise \\
\hline Associate's Degree & 0.09 & 1 if earned associate's degree, 0 otherwise \\
\hline Bachelor's Degree & 0.13 & 1 if earned bachelor's degree, 0 otherwise \\
\hline Master's Degree + & 0.08 & 1 if earned master's degree or higher, 0 otherwise \\
\hline Age 30-39 & 0.15 & 1 if $30 \leq$ age $\leq 39,0$ otherwise \\
\hline Age 40-49 & 0.22 & 1 if $40 \leq$ age $\leq 49,0$ otherwise \\
\hline Age 50-64 & 0.27 & 1 if $50 \leq$ age $\leq 64,0$ otherwise \\
\hline Age 65+ & 0.14 & 1 if age $\geq 65$ \\
\hline Age Missing & 0.02 & 1 if no response to age question, 0 otherwise \\
\hline Female & 0.55 & 1 if female, 0 otherwise \\
\hline White & 0.88 & 1 if white, 0 otherwise \\
\hline Taken a Class & 0.27 & $\begin{array}{l}1 \text { if respondents has taken a class from KCTCS, } 0 \\
\text { otherwise }\end{array}$ \\
\hline Family Attended & 0.53 & 1 if a family member has attended KCTCS, 0 otherwise \\
\hline Know Employee & 0.27 & $\begin{array}{l}1 \text { if respondent knows someone that works for KCTCS, } \\
0 \text { otherwise }\end{array}$ \\
\hline Web & 0.1 & 1 if survey was web-based, 0 if mail-based \\
\hline Cheap Talk Minus 10 & 0.22 & $\begin{array}{l}1 \text { if received cheap talk treatment } \& 10 \% \text { reduction } \\
\text { scenario, } 0 \text { otherwise }\end{array}$ \\
\hline Cheap Talk Minus 25 & 0.24 & $\begin{array}{l}1 \text { if received cheap talk treatment } \& 25 \% \text { reduction } \\
\text { scenario, } 0 \text { otherwise }\end{array}$ \\
\hline
\end{tabular}

Note: The standard deviation for the non-categorical variable is shown in brackets. Means calculated using estimation sample, $\mathrm{n}=1023$. The number of respondents who said "yes" and were definitely sure is 272 . This means that the dependent variable takes on a value of 1 for 0.27 of the sample. 
Table 3. Logistic Regression Results with Dependent Variable equal to "Definitely Sure"

\begin{tabular}{lccc}
\hline \hline & Coefficient & $\begin{array}{c}\text { Standard } \\
\text { Error }\end{array}$ & $\begin{array}{c}\text { Marginal } \\
\text { Effect }\end{array}$ \\
\hline Tax Amount & $-0.0047^{* * *}$ & 0.0007 & $-0.0008^{* * *}$ \\
Income \$25K-39K & -0.0759 & 0.2938 & -0.0131 \\
Income \$40K-59K & 0.3645 & 0.2843 & 0.0675 \\
Income \$60K-99K & $0.6662^{* *}$ & 0.2854 & $0.1278^{* *}$ \\
Income > \$100K & $1.1486 * * *$ & 0.3247 & $0.2411^{* * *}$ \\
Income Missing & -0.4103 & 0.453 & -0.0648 \\
High School Diploma & -0.0146 & 0.403 & -0.0026 \\
Some College & 0.452 & 0.4131 & 0.0844 \\
Associate's Degree & $0.8397 *$ & 0.4644 & 0.1726 \\
Bachelor's Degree & 0.5855 & 0.4293 & 0.1124 \\
Master's Degree + & 0.3828 & 0.435 & 0.0716 \\
Age 30-39 & 0.1975 & 0.4659 & 0.036 \\
Age 40-49 & 0.4313 & 0.4461 & 0.0807 \\
Age 50-64 & $0.8695^{* *}$ & 0.4276 & $0.1602 *$ \\
Age 65 & $1.0286 * *$ & 0.4488 & $0.2069 * *$ \\
Age Missing & -0.4142 & 1.1418 & -0.0646 \\
Female & -0.0363 & 0.1662 & -0.0064 \\
White & -0.2819 & 0.3525 & -0.0527 \\
Taken a Class & -0.231 & 0.2054 & -0.0393 \\
Family Attended & $0.4527 * * *$ & 0.1737 & $0.0794 * * *$ \\
Know Employee & $0.3630 * *$ & 0.1748 & $0.0662 * *$ \\
Web & 0.0091 & 0.244 & 0.0016 \\
Cheap Talk Minus 10 & $0.8032 * * *$ & 0.186 & $0.1553^{* * *}$ \\
Cheap Talk Minus 25 & $0.7958 * * *$ & 0.1904 & $0.1550^{* * *}$ \\
Constant & $-2.1981^{* * *}$ & 0.6469 & \\
\hline Sample Size & 1023 & & \\
Likelihood Ratio Statistic & & \\
Pseudo R-squared & 157.24 & & \\
\hline \hline & 0.1327 & & \\
\hline
\end{tabular}

Note: The dependent variable "Definitely Sure" equals one for respondents definitely sure of their affirmative response and zero otherwise. Base categories for income, education, and age are respectively, Under \$25,000, Less than a High School Diploma, Age 18-25. Standard errors in parentheses. ${ }^{* * *} \mathrm{p}<0.01,{ }^{* *} \mathrm{p}<0.05,{ }^{*} \mathrm{p}<0.1$. 
Table 4. Respondents' Beliefs about the Benefits of Education and Training

\begin{tabular}{|c|c|c|c|c|}
\hline & Mean & $\begin{array}{c}\text { Standard } \\
\text { Deviation }\end{array}$ & Minimum & Maximum \\
\hline Economic Development & 18.14 & 12.31 & 0 & 100 \\
\hline Technology & 13.54 & 10.43 & 0 & 100 \\
\hline Wages of Attendees & 13.23 & 10.21 & 0 & 100 \\
\hline Crime & 12.02 & 11.6 & 0 & 100 \\
\hline Better Public Decision Making & 11.31 & 9.19 & 0 & 100 \\
\hline Own health & 10.33 & 8.67 & 0 & 100 \\
\hline Local Purchases & 8.46 & 7.14 & 0 & 50 \\
\hline Wages of Non-Attendees & 6.6 & 6.58 & 0 & 60 \\
\hline Health of Non-Attendees & 6.39 & 6.95 & 0 & 60 \\
\hline
\end{tabular}

This table is based on 988 observations from the 1,023 logit estimation sample. 35 observations had missing data for the question about the benefits of education. 
Table 5. Log Earnings Equations, 2000 U.S. Census Data for Kentucky

\begin{tabular}{|c|c|c|}
\hline & Males & Females \\
\hline \multicolumn{3}{|l|}{ Education } \\
\hline Less than One Year of College & $\begin{array}{r}0.161^{* * *} \\
(0.016)\end{array}$ & $\begin{array}{r}0.178 * * * \\
(0.018)\end{array}$ \\
\hline Year or More of College, No Degree & $\begin{array}{r}0.117^{* * *} \\
(0.012)\end{array}$ & $\begin{array}{r}0.159 * * * \\
(0.014)\end{array}$ \\
\hline Associate's Degree & $\begin{array}{r}0.243^{* * *} \\
(0.018)\end{array}$ & $\begin{array}{r}0.438 * * * \\
(0.018)\end{array}$ \\
\hline Bachelor's Degree & $\begin{array}{r}0.555^{* * *} \\
(0.012)\end{array}$ & $\begin{array}{r}0.672 * * * \\
(0.016)\end{array}$ \\
\hline Master’s Degree & $\begin{array}{r}0.570 * * * \\
(0.019)\end{array}$ & $\begin{array}{r}0.838 * * * \\
(0.020)\end{array}$ \\
\hline Professional or Doctoral Degree & $\begin{array}{r}0.975^{* * *} \\
(0.023)\end{array}$ & $\begin{array}{r}1.092 * * * \\
(0.035)\end{array}$ \\
\hline \multicolumn{3}{|l|}{ Experience } \\
\hline Potential Years & $\begin{array}{r}0.0715^{* * * *} \\
(0.002)\end{array}$ & $\begin{array}{r}0.0626^{* * *} \\
(0.002)\end{array}$ \\
\hline Potential Years Squared & $\begin{array}{r}0.00138 * * * \\
(0.000)\end{array}$ & $\begin{array}{r}0.00113 * * * \\
(0.000)\end{array}$ \\
\hline \multicolumn{3}{|l|}{ Socio-demographic } \\
\hline Black & $\begin{array}{r}-0.233 * * * \\
(0.018)\end{array}$ & $\begin{array}{r}0.0157 \\
(0.020)\end{array}$ \\
\hline Married & $\begin{array}{r}0.419 * * * \\
(0.012)\end{array}$ & $\begin{array}{r}-0.0128 \\
(0.015)\end{array}$ \\
\hline Divorced & $\begin{array}{r}0.180^{* * *} \\
(0.017) \\
\end{array}$ & $\begin{array}{r}0.114^{* * *} \\
(0.018)\end{array}$ \\
\hline Constant & $\begin{array}{r}9.029 * * * \\
(0.014) \\
\end{array}$ & $\begin{array}{r}8.712^{* * *} \\
(0.018) \\
\end{array}$ \\
\hline Observations & 38583 & 37396 \\
\hline R-squared & 0.244 & 0.141 \\
\hline
\end{tabular}

Note: Standard errors in parentheses. ${ }^{* * *} \mathrm{p}<0.01,{ }^{* *} \mathrm{p}<0.05,{ }^{*} \mathrm{p}<0.1$. The omitted education category is high school or less. The dependent variable is the log of annual earnings. All earnings data have been converted to 2007 dollars using the CPI-U. 
Table 6. Log Earnings Equations with Individual and Time Fixed Effects, KCTCS Administrative Data.

\begin{tabular}{lcc}
\hline \hline Education & Males & Females \\
Associate's Degree & & \\
& & \\
& $\left(0.105^{* * *}\right.$ & $0.319 * * *$ \\
Diploma & & $(0.013)$ \\
& $0.067 * * *$ & $0.300 * * *$ \\
Certificate & $(0.021)$ & $(0.013)$ \\
& & \\
& -0.01 & $0.072 * * *$ \\
Observations & $(0.018)$ & $(0.013)$ \\
Students & & 228,285 \\
R-squared & 204,108 & 12171 \\
\hline \hline
\end{tabular}

Note: Standard errors in parentheses. ${ }^{* * *} \mathrm{p}<0.01,{ }^{* *} \mathrm{p}<0.05,{ }^{*} \mathrm{p}<0.1$. These data include students who enrolled in KCTCS from 2002-2003. Earnings data are from 2000-2006. The dependent variable is the log of quarterly earnings. All earnings data have been converted to 2007 dollars using the CPI-U. The equation estimated includes variables for age, age squared, interactions with nonwhite in addition to individual and time (quarter) fixed effects. 
Table 7. Individual Lifetime Earnings Gain from KCTCS Degree, Diploma, or Certificate

\begin{tabular}{lcc}
\hline \hline & Males & Females \\
\hline Census Data & & \\
Associate's Degree & $\$ 63,822$ & $\$ 92,148$ \\
& & \\
KCTCS Administrative Data & & \\
& & \\
Associate's Degree & $\$ 46,721$ & $\$ 95,895$ \\
Diploma & $\$ 26,702$ & $\$ 92,297$ \\
Certificate & $-\$ 15,297$ & $\$ 13,909$ \\
\hline \hline
\end{tabular}

Note: The individual lifetime earnings gains reported in this table are measured relative to estimated lifetime earnings of a high school graduate and assuming the individual receives the degree, diploma, or certificate at age 20. Because not all are achieved at age 20, our estimates of the gains from a 10\% expansion of the KCTCS system are based on the distribution of ages when degrees, diplomas, and certificates are actually earned in the KCTCS data. The individual lifetime earnings gains reported in this table are based on a discount rate of $2.8 \%$ and include work and survival probabilities. 
Table 8. Predicted Lifetime Private Returns for $10 \%$ Expansion to KCTCS, Kentucky.

\section{Models Males}

Females

Total

Census - Associate's Degree

With age-adjusted work and survival probabilities (preferred estimate)

$\mathbf{\$ 1 6 , 0 8 0 , 9 1 9} \mathbf{\$ 4 5 , 1 2 9 , 1 7 3}$

$\$ 61,210,093$

with age-adjusted work probabilities and controls for industry, occupation

$\$ 17,555,003 \quad \$ 31,501,456$

$\$ 49,056,459$

no adjustment for work probability or survival

$\$ 26,274,228 \quad \$ 82,994,551 \quad \$ 109,268,779$

\section{KCTCS}

With age-adjusted work probabilities

Associate's Degree

\begin{tabular}{rrr}
$\$ 7,145,350$ & $\$ 33,997,917$ & $\$ 41,143,267$ \\
$\$ 1,279,582$ & $\$ 10,859,507$ & $\$ 12,139,089$ \\
$-\$ 9,714,560$ & $\$ 4,813,923$ & $-\$ 4,900,637$ \\
$\mathbf{- \$ 1 , 2 8 9 , 6 2 8}$ & $\mathbf{\$ 4 9 , 6 7 1 , 3 4 7}$ & $\mathbf{\$ 4 8 , 3 8 1 , 7 1 9}$ \\
& & \\
$\$ 11,402,510$ & $\$ 57,931,606$ & $\$ 69,334,116$ \\
$\$ 2,983,085$ & $\$ 20,262,610$ & $\$ 23,245,695$ \\
- & & \\
$\$ 10,564,745$ & $\$ 11,724,282$ & $\$ 1,159,537$ \\
$\$ 3,820,850$ & $\$ 89,918,498$ & $\$ 93,739,347$ \\
\hline
\end{tabular}

Diploma

Certificate

TOTAL (preferred estimate)

No adjustment for work probability or survival

Associate's Degree

Diploma

$\$ 3,820,850 \quad \$ 89,918,498$

Note: The estimated return is measured as an increase in earnings relative to a high school graduate, in 2007 dollars. All predictions are discounted to the present using an annual rate of 2.8\%; returns are less foregone earnings (1 year for Associate’s Degree; 0.75 years for Diploma; and 0.5 years for Certificate) and the real cost of tuition, books, and fees ( $\$ 8,003$ for Associate’s Degree; $0.75 * 8003$ for Diploma; $0.5 * 8003$ for Certificate). 
Table 9. Log Earnings Equation with Area-wide Education, 2000 U.S. Census Data for Kentucky

\begin{tabular}{|c|c|c|c|c|c|c|}
\hline & \multicolumn{4}{|c|}{ Males } & \multicolumn{2}{|c|}{ Females } \\
\hline & $(1)$ & $(2)$ & (3) & (4) & (5) & $(6)$ \\
\hline \multicolumn{7}{|l|}{ Individual Education } \\
\hline Less than One Year of College & $\begin{array}{c}0.143 * * * \\
(0.0156)\end{array}$ & $\begin{array}{c}0.145^{* * *} \\
(0.0156)\end{array}$ & $\begin{array}{c}0.143 * * * \\
(0.0156)\end{array}$ & $\begin{array}{c}0.161^{* * *} \\
(0.0179)\end{array}$ & $\begin{array}{c}0.164 * * * \\
(0.0179)\end{array}$ & $\begin{array}{c}0.163 * * * \\
(0.0179)\end{array}$ \\
\hline \multicolumn{7}{|l|}{ Year or More of College, No } \\
\hline Degree & $\begin{array}{c}0.0865^{* * *} \\
(0.0117)\end{array}$ & $\begin{array}{c}0.0866 * * * \\
(0.0118)\end{array}$ & $\begin{array}{c}0.0846 * * * \\
(0.0117)\end{array}$ & $\begin{array}{c}0.132 * * * \\
(0.0141)\end{array}$ & $\begin{array}{c}0.132 * * * \\
(0.0142)\end{array}$ & $\begin{array}{c}0.131^{* * *} \\
(0.0141)\end{array}$ \\
\hline Associate's Degree & $\begin{array}{c}\mathbf{0 . 2 0 9 * * *} \\
(0.0184)\end{array}$ & $\begin{array}{c}\mathbf{0 . 2 2 2} * * * \\
(0.0184)\end{array}$ & $\begin{array}{c}\mathbf{0 . 2 0 9} * * * \\
(0.0184)\end{array}$ & $\begin{array}{c}\mathbf{0 . 4 1 6} * * * \\
(0.0183)\end{array}$ & $\begin{array}{c}\mathbf{0 . 4 1 6} * * * \\
(0.0183)\end{array}$ & $\begin{array}{c}\mathbf{0 . 4 1 4} * * * \\
(0.0183)\end{array}$ \\
\hline Bachelor's Degree & $\begin{array}{c}0.488 * * * \\
(0.0127)\end{array}$ & $\begin{array}{c}0.484 * * * \\
(0.0128)\end{array}$ & $\begin{array}{c}0.480 * * * \\
(0.0128)\end{array}$ & $\begin{array}{c}0.610 * * * \\
(0.0159)\end{array}$ & $\begin{array}{c}0.605^{* * *} \\
(0.0161)\end{array}$ & $\begin{array}{c}0.603^{* * *} \\
(0.0161)\end{array}$ \\
\hline Master's Degree & $\begin{array}{c}0.508 * * * \\
(0.0192)\end{array}$ & $\begin{array}{c}0.501 * * * \\
(0.0193)\end{array}$ & $\begin{array}{c}0.497 * * * \\
(0.0193)\end{array}$ & $\begin{array}{c}0.791 * * * \\
(0.0197)\end{array}$ & $\begin{array}{c}0.783^{* * *} \\
(0.0199)\end{array}$ & $\begin{array}{c}0.782^{* * *} \\
(0.0198)\end{array}$ \\
\hline Professional or Doctoral Degree & $\begin{array}{c}0.898 * * * \\
(0.0231)\end{array}$ & $\begin{array}{c}0.887 * * * \\
(0.0223)\end{array}$ & $\begin{array}{c}0.884 * * * \\
(0.0233)\end{array}$ & $\begin{array}{l}1.029 * * * \\
(0.0351)\end{array}$ & $\begin{array}{l}1.015^{* * *} \\
(0.0352)\end{array}$ & $\begin{array}{l}1.014^{* * *} \\
(0.0352)\end{array}$ \\
\hline \multicolumn{7}{|l|}{ Region Level Education } \\
\hline Average Years of Schooling & $\begin{array}{c}0.0796 * * * \\
(0.00377)\end{array}$ & & & $\begin{array}{c}0.0823 * * * \\
(0.00447)\end{array}$ & & \\
\hline Percent Bachelor’s or More & & $\begin{array}{c}0.739 * * * \\
-0.0383\end{array}$ & & & $\begin{array}{c}0.746 * * * \\
-0.0447\end{array}$ & \\
\hline Percent Associate's or More & & & $\begin{array}{c}\mathbf{0 . 7 3 9} * * * \\
(0.0363) \\
\end{array}$ & & & $\begin{array}{c}\mathbf{0 . 7 2 8} * * * \\
(0.0423) \\
\end{array}$ \\
\hline \multicolumn{7}{|l|}{ Experience } \\
\hline Potential Years & $\begin{array}{c}0.0702 * * * \\
(0.00157)\end{array}$ & $\begin{array}{c}0.0709 * * * \\
-0.00157\end{array}$ & $\begin{array}{c}0.0700^{* * *} \\
-0.00157\end{array}$ & $\begin{array}{c}0.0616^{* * *} \\
(0.00176)\end{array}$ & $\begin{array}{c}0.0621^{* * *} \\
-0.00176\end{array}$ & $\begin{array}{c}0.0621 * * * \\
-0.00176\end{array}$ \\
\hline Potential Years Squared & $\begin{array}{c}- \\
0.00136^{* * *} \\
(0.0000374)\end{array}$ & $\begin{array}{c}- \\
0.00137^{* * *} \\
(0.0000374)\end{array}$ & $\begin{array}{c}- \\
0.00137^{* * *} \\
(0.0000374)\end{array}$ & $\begin{array}{c}- \\
0.00112^{* * *} \\
(0.0000426)\end{array}$ & $\begin{array}{c}- \\
0.00113^{* * *} \\
(0.0000427)\end{array}$ & $\begin{array}{c}- \\
0.00114^{* * *} \\
(0.0000427)\end{array}$ \\
\hline \multicolumn{7}{|l|}{ Socio-demographic } \\
\hline Black & $\begin{array}{c}-0.234^{* * *} \\
(0.0178)\end{array}$ & $\begin{array}{c}-0.233^{* * *} \\
(0.0178)\end{array}$ & $\begin{array}{c}-0.236 * * * \\
(0.0178)\end{array}$ & $\begin{array}{c}0.0122 \\
(0.0197)\end{array}$ & $\begin{array}{l}-0.0169 \\
(0.0198)\end{array}$ & $\begin{array}{c}-0.0141 \\
(0.0198)\end{array}$ \\
\hline Married & $\begin{array}{c}0.440 * * * \\
(0.0123)\end{array}$ & $\begin{array}{c}0.437 * * * \\
(0.0123)\end{array}$ & $\begin{array}{c}0.438 * * * \\
(0.0123)\end{array}$ & $\begin{array}{c}0.0123 \\
(0.0150)\end{array}$ & $\begin{array}{l}0.00822 \\
(0.0150)\end{array}$ & $\begin{array}{l}0.00816 \\
(0.0150)\end{array}$ \\
\hline Divorced & $\begin{array}{c}0.194^{* * *} \\
(0.0165) \\
\end{array}$ & $\begin{array}{c}0.195^{* * *} \\
(0.0165) \\
\end{array}$ & $\begin{array}{c}0.195^{* * *} \\
(0.0165) \\
\end{array}$ & $\begin{array}{c}0.130 * * * \\
(0.0183) \\
\end{array}$ & $\begin{array}{c}0.127^{* * *} \\
(0.0183) \\
\end{array}$ & $\begin{array}{c}0.127^{* * *} \\
(0.0183)\end{array}$ \\
\hline Constant & $\begin{array}{c}8.104^{* * *} \\
(0.0460) \\
\end{array}$ & $\begin{array}{c}8.912 * * * \\
(0.0153) \\
\end{array}$ & $\begin{array}{c}8.878^{* * *} \\
(0.0159) \\
\end{array}$ & $\begin{array}{l}7.748^{* * *} \\
(0.0552) \\
\end{array}$ & $\begin{array}{c}8.592 * * * \\
(0.0189) \\
\end{array}$ & $\begin{array}{c}8.561^{* * *} \\
(0.0196) \\
\end{array}$ \\
\hline Observations & 38583 & 38583 & 38583 & 37396 & 37396 & 37396 \\
\hline R-squared & 0.252 & 0.251 & 0.252 & 0.149 & 0.147 & 0.148 \\
\hline
\end{tabular}

Note: Standard errors in parentheses. ${ }^{* * *} \mathrm{p}<0.01,{ }^{* *} \mathrm{p}<0.05,{ }^{*} \mathrm{p}<0.1$. The dependent variable is the log of annual earnings. All earnings have been converted to 2007 dollars using the CPI-U. 
Figure 1. Parametric Demand Curves for Ten Percent Expansion of KCTCS (definitely sure “yes" and all "yes")

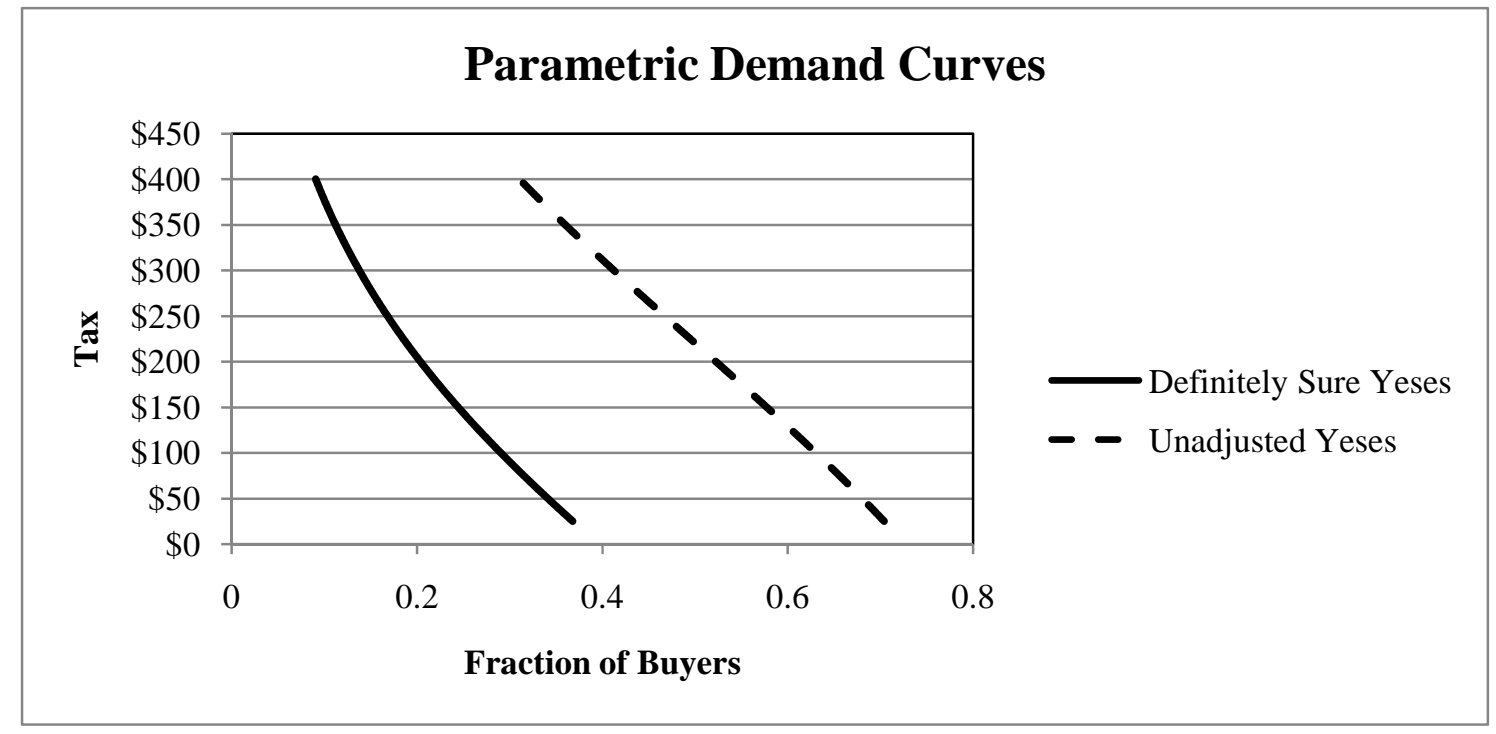

The sample size for the the logit from which the demand curve is estimated is 1023 for both demand curves. For the Definitely Sure Yeses, only the 272 definitely sure "yes" responses were coded as 1; all others were 0 . For the Undadjusted Yeses, all 564 "yes" responses were coded as 1 and all "no" responses were coded as 0 . 


\section{Appendix}

Table A1. Logistic Regression Results with Additional Independent Variables $\dagger$

\begin{tabular}{lrcc}
\hline & Coefficient & Standard Error \\
\hline Tax Amount & -0.0048 & $* * *$ & 0.0007 \\
HINC \$25K-39K & 0.0348 & & 0.3023 \\
HINC \$40K-59K & 0.3723 & & 0.2969 \\
HINC \$60K-99K & 0.7444 & $* *$ & 0.2956 \\
HINC > \$100K & 1.2318 & $* * *$ & 0.3362 \\
HINC Missing & -0.2172 & & 0.4675 \\
HS Diploma & -0.1360 & & 0.4165 \\
Some College & 0.3280 & 0.4342 \\
Associate's Degree & 0.6016 & 0.4866 \\
Bachelor's Degree & 0.4027 & 0.4500 \\
Master's Degree + & 0.2027 & 0.4606 \\
Age 30-39 & 0.2332 & 0.4773 \\
Age 40-49 & 0.4137 & 0.4622 \\
Age 50-64 & 0.8766 & $*$ & 0.4514 \\
Age 65 & 1.0347 & $* *$ & 0.4946 \\
Age Missing & -0.4638 & & 1.1530 \\
Female & 0.0050 & 0.1723 \\
White & -0.2710 & & 0.3722 \\
Taken a Class & -0.2575 & & 0.2145 \\
Family Attended & 0.4191 & $* *$ & 0.1816 \\
Know Employee & 0.2970 & 0.1854 \\
Web & -0.0448 & & 0.2464 \\
Cheap Talk Minus 10 & 0.7994 & $* * *$ & 0.1967 \\
Cheap Talk Minus 25 & 0.8500 & $* * *$ & 0.1912 \\
Quality of Life & -0.0043 & & 0.0073 \\
Productivity Growth & -0.0009 & 0.0068 \\
County & 0.2154 & 0.1968 \\
Population Density & -0.0001 & 0.0001 \\
Years in Kentucky & -0.0014 & & 0.0050 \\
Constant & -1.9132 & $* *$ & 0.8047 \\
\hline Sample Size & & & \\
Likelihood Ratio Statistic & 949 & & \\
Pseudo R-squared & 0.1364 & & \\
\hline & & & \\
\hline
\end{tabular}

$†$ The dependent variable "Definitely Sure" equals one for respondents definitely sure of their affirmative response and zero otherwise. Base categories for income, education, and age are respectively: Under $\$ 25,000$, Less than a High School Diploma, Age 18-25. Significance is shown as $* * * p<0.01,{ }^{* *} \mathrm{p}<0.05$, $* \mathrm{p}<0.1$. 
Table A2. Predicted Lifetime Private Returns to KCTCS, Kentucky increase in present value of earnings, compared to high school diploma, in 2007 dollars

\begin{tabular}{|c|c|c|}
\hline Models & & Total \\
\hline Total Social Return & & $\$ 92,400,000$ \\
\hline \multicolumn{3}{|c|}{ Census - Private Return, with age-adjusted work and survival probabilities } \\
\hline & $1 \%$ discount rate & $\$ 88,842,409$ \\
\hline & $2.8 \%$ discount rate & $\$ 61,210,093$ \\
\hline & $4 \%$ discount rate & $\$ 48,468,874$ \\
\hline
\end{tabular}

KCTCS - Private Return, with age-adjusted work and survival probabilities

$1 \%$ discount rate

$\$ 74,199,696$

$2.8 \%$ discount rate $\$ 48,381,719$

$4 \%$ discount rate $\$ 36,029,961$ 